\title{
Alterations in transcript abundance of bovine oocytes recovered at growth and dominance phases of the first follicular wave Nasser Ghanem ${ }^{1}$, Michael Hölker ${ }^{1}$, Franca Rings' ${ }^{1}$, Danyel Jennen ${ }^{1}$, Ernst Tholen ${ }^{1}$, Marc-André Sirard ${ }^{2}$, Helmut Torner ${ }^{3}$, Wilhelm Kanitz ${ }^{3}$, Karl Schellander ${ }^{1}$ and Dawit Tesfaye*1
}

\begin{abstract}
Address: ${ }^{1}$ Institute of Animal Science, Animal Breeding and Husbandry Group, University of Bonn, 53115 Bonn, Germany, ${ }^{2}$ Centre de Recherche en Biologie de la Reproduction, Université Laval, Département des Sciences Animales, Pav. Comtois, Laval, Sainte-Foy, Québec, G1K 7P4, Canada and ${ }^{3}$ Research Institute for Biology of Farm Animals, Wilhelm-Stahl-Allee 2, 18196 Dummerstorf, Germany

Email: Nasser Ghanem - ngha@itw.uni-bonn.de; Michael Hölker - mhoe@itw.uni-bonn.de; Franca Rings - rings@itw.uni-bonn.de; Danyel Jennen - djen@itw.uni-bonn.de; Ernst Tholen - etho@itw.uni-bonn.de; Marc-André Sirard - marc-andre.sirard@crbr.ulaval.ca; Helmut Torner - torner@fbn-dummerstorf.de; Wilhelm Kanitz - wkanitz@fbn-dummerstorf.de; Karl Schellander - ksch@itw.uni-bonn.de; Dawit Tesfaye* - tesfaye@itw.uni-bonn.de

* Corresponding author
\end{abstract}

Published: 27 July 2007

BMC Developmental Biology 2007, 7:90 doi:10.1/86/147I-2I3X-7-90
Received: 6 February 2007

Accepted: 27 July 2007

This article is available from: http://www.biomedcentral.com/I47I-2/3X/7/90

(C) 2007 Ghanem et al; licensee BioMed Central Ltd.

This is an Open Access article distributed under the terms of the Creative Commons Attribution License (http://creativecommons.org/licenses/by/2.0), which permits unrestricted use, distribution, and reproduction in any medium, provided the original work is properly cited.

\begin{abstract}
Background: Oocyte developmental competence is highly affected by the phase of ovarian follicular wave. Previous studies have shown that oocytes from subordinate follicles recovered at growth phase (day 3 after estrus) are developmentally more competent than those recovered at dominance phase (day 7 after estrus). However, the molecular mechanisms associated with these differences are not well elucidated. Therefore, the objective of this study was to investigate transcript abundance of bovine oocytes retrieved from small follicles at growth and dominance phases of the first follicular wave and to identify candidate genes related to oocyte developmental competence using cDNA microarray.

Results: Comparative gene expression analysis of oocytes from growth and dominance phases and subsequent data analysis using Significant Analysis of Microarray (SAM) revealed a total of $5 \mathrm{I}$ differentially regulated genes, including 36 with known function, 6 with unknown function and 9 novel transcripts. Real-time PCR has validated 10 transcripts revealed by microarray analysis and quantified 5 genes in cumulus cells derived from oocytes of both phases. The expression profile of 8 (80\%) transcripts (ANAXA2, FL396, SI00A I0, RPL24, PP, PTTGI, MSXI and BMPI5) was in agreement with microarray data. Transcript abundance of five candidate genes in relation to oocyte developmental competence was validated using Brilliant Cresyl Blue (BCB) staining as an independent model. Furthermore, localization of mRNA and protein product of the candidate gene MSXI in sections of ovarian follicles at days 0, I, 3 and 7 of estrous cycle showed a clear fluorescent signal in both oocytes and cumulus cells with higher intensity in the former. Moreover, the protein product was detected in bovine oocytes and early cleavage embryos after fertilization with higher intensity around the nucleus.

Conclusion: This study has identified distinct sets of differentially regulated transcripts between bovine oocytes recovered from small follicles at growth and dominance phases of the first follicular wave. The validation with independent model supports our notion that many of the transcripts identified here may represent candidate genes associated with oocyte developmental competence. Further specific functional analysis will provide insights into the exact role of these transcripts in oocyte competence and early embryonic development.
\end{abstract}




\section{Background}

In vitro embryo production depends on the collection of immature oocytes from heterogeneous follicular population of slaughterhouse ovaries. Despite the desire to expand the field application of this technology in cattle, the blastocyst development is limited to $30-40 \%$ with only half of these being able to initiate a successful pregnancy following transfer $[1,2]$. One of the main factors affecting the embryo yield is the intrinsic quality of the oocyte, while the embryo culture condition plays a crucial role in determining embryo quality [3].

There is a general agreement that oocyte developmental competence is related to follicule size [4], estrous cycle stage [5] and the level of atresia influenced by other follicles, mainly the dominant follicle [6] and morphological features of the oocyte [7]. Follicle size and oocyte diameter are closely related, and as both increase the developmental potential of the oocyte also increases [8-10]. However, various studies revealed that the developmental competence of an oocyte is related to the status of the follicle from which it is obtained regardless of follicle size [11-13].

As soon as the primordial follicle store is established, follicle recruitment begins and continues in a wave-like pattern during estrous cycles. Bovine estrous cycle is characterized by a series of two or three follicular waves [14-16]. Within several days of initiation of a wave, one follicle is selected as the dominant follicle, which continues to grow and differentiate, whereas its sister subordinate follicles plateau in growth and then regress. The interactions between the follicles throughout each follicular wave affect oocyte quality. It was reported [6,17-21] that development of early embryos to the blastocyst stage was greater when oocytes are obtained during follicular growth/stagnation phase $(\mathrm{G} / \mathrm{S})$ than in the dominance/ regression phase $(D / R)$. The dominant follicle exerts a direct inhibitory effect on the development of subordinate follicles [22], causing them to undergo atresia [23], which lead to lower in vitro developmental competence compared to their counterparts at growth phase [6]. In addition, blastocysts derived from oocytes collected from both medium and small follicles at $\mathrm{G} / \mathrm{S}$ stage or $\mathrm{D} / \mathrm{R}$ stage were reported to be different in relative abundance of transcripts related to embryonic development [24].

To our knowledge, the mRNA transcript abundance of oocytes recovered at different stages of ovarian follicular turnover in bovine has not yet been analyzed. Therefore, in the present study we aimed to identify the differences in the transcript abundance of bovine oocytes retrieved from small follicles at growth and dominance phases which could be associated with oocyte developmental potential. With this approach, we have identified differen- tially expressed genes in oocytes derived from these two stages. Differences in transcript abundance of some transcripts of interest between the two oocyte groups and cumulus cells were examined using quantitative real-time PCR. An independent model has been used to validate the expression profile of some selected transcripts in oocytes screened for differences in their developmental competence.

In addition, MSX1 gene was selected for further analysis due to the following reasons: 1 ) it has also been identified as differentially regulated transcript between biopsies derived from blastocysts resulted in pregnancy and no pregnancy in our previous study [25] 2) results from previous studies $[26,27]$ suggest a physiologically optimal level of MSX1 expression is vital for normal cellular function. However, so far this transcript has not been characterized in early embryonic development and follicular turnover. The distribution of protein products and mRNA for MSX1 during ovarian follicular turnover and early embryonic development has been evidenced in this study.

\section{Results}

\section{Follicle distribution and oocyte recovery}

As shown in Table 1, ultrasound guided ovum pick up (OPU) of sixty cyclic heifers showed that ovaries of both growth and dominance phases had greater number of small follicles (3-5 $\mathrm{mm}$ ) than medium and large follicles. Moreover, a higher number of small and medium follicles $(\mathrm{n}=333$ ) has been found at growth phase compared to dominance phase $(n=262)$. Consequently, the average number of oocytes collected per cow was greater during growth phase $(7.7 \pm 3.5)$ than in the dominance phase $(4.9 \pm 2.1)$.

\section{Comparative transcript abundance of oocytes recovered at growth and dominance phases}

In the present study, a series of six hybridizations (three biological replicates with dye swaps) were conducted to minimize the false positive expression changes and to identify genes truly differentially expressed between oocytes recovered from growth and dominance phases. The generated data are available on our website of Bonn University [28], under the research section for OPU-IVF. After LOWESS normalization of the data, log value of Cy5 total intensity was compared with the log value of $\mathrm{Cy} 3$ total intensity for both the target (Fig. 1A) and the respective dye swap hybridizations (Fig. 1B). The coefficient of determination of the target $\left(\mathrm{R}^{2}=0.96\right)$ and dye swap $\left(\mathrm{R}^{2}\right.$ $=0.95$ ) hybridizations were found to be relatively the same which confirms that there was low false positive expression changes between hybridizations of differentially labeled (Cy5 and Cy3) cDNA from the same phase (growth and dominance). 

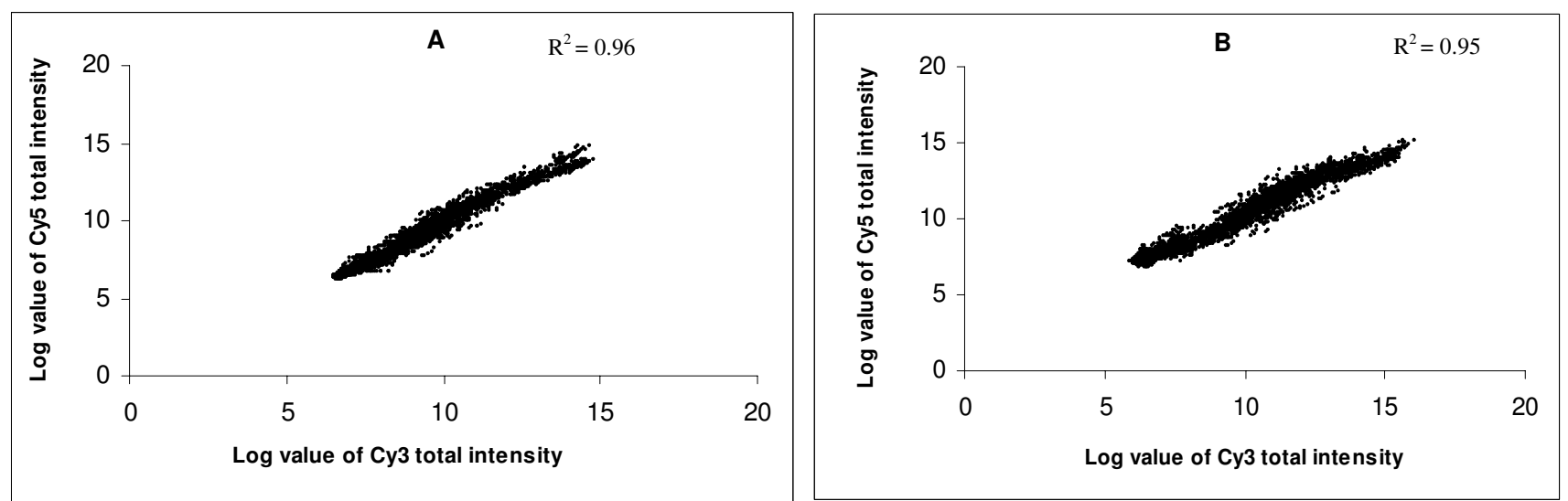

\section{Figure I}

Scatter plot illustrating log value of $\mathrm{Cy} 3, \mathrm{Cy} 5$ total intensities for the biological and dye swap (technical) replicates. Each gene is represented by a point of $\mathrm{Cy} 3$ and Cy5 log values, A: represents target hybridizations B: represents dye swap hybridizations.

To obtain a highly confident set of differentially expressed genes, we used a rigorous combination of $P$-value $(P<$ 0.05 ) and fold discovery rate (FDR) of $10 \%$. Accordingly, the data analysis performed by SAM showed that 51 transcripts were differentially regulated between the two oocyte populations. The threshold for significant variation was set at 1.5 fold change. Using this criterion, genes were sorted into two categories based on their variation factor: those for which the relative transcript abundance increased (up-regulated) or decreased (down-regulated) in growth phase versus dominance phase oocytes. The fold change was in a range of 1.5 to 5.3 for up-regulated and 1.5 to 2.6 for down-regulated genes in growth phase compared to dominance phase oocytes (Fig. 2, Tab. 2 and $3)$.

Hierarchical clustering and heatmap of differentially regulated genes showed the overall expression pattern between the two oocyte groups. The average linkage clustering analysis revealed the presence of many subgroups (or clusters) within the up- and down-regulated genes sharing similar expression pattern (Fig. 2).
Functional classification of differentially regulated genes All differentially regulated transcripts were functionally classified based on the criteria of Gene Ontology Consortium classifications [29]. The resulting data were supplemented with additional information from various tools available in National Center for Biotechnology Information [30]. Accordingly, the differentially regulated transcripts represent genes with known function $(36 / 51)$, genes with unknown function (6/51) and novel transcripts (9/51) (Fig. 3). Regarding the molecular function, transcripts with known function showed to be involved in protein biosynthesis (18\%), transcription (10\%), cytoskeleton (8\%), cell cycle (8\%), NADH dehydrogenase activity (4\%), calcium ion binding (4\%), nucleotide binding $(4 \%)$ and other functions $(10 \%)$. Oocytes recovered at growth phase (Tab. 2) were enriched with genes regulating protein biosynthesis (RPLP0, RPL8, RPL24, ARL6IP, RpS14, RpS15, RpS4x and RPS3A), translation elongation (EF1A), ATP binding (ATP5A1), NADH dehydrogenase activity (FL396 and FL405), cytoskeleton (Actin, betaActin, H2AZ and KRT8), calcium ion binding (S100A10 and ANXA2), signal transduction (G-beta like protein),

Table I: Performance of the OPU procedure at growth and dominance phases of follicular development

\begin{tabular}{|c|c|c|c|c|c|}
\hline $\begin{array}{c}\text { Phase of follicular } \\
\text { development }\end{array}$ & Follicle size & $\begin{array}{c}\text { Number of follicles } \\
\text { aspirated }\end{array}$ & $\begin{array}{c}\text { Number of oocytes } \\
\text { retrieved }\end{array}$ & $\begin{array}{l}\text { Average number of } \\
\text { oocytes per animal }\end{array}$ & Recovery rate \\
\hline \multirow[t]{3}{*}{ Growth $(n=30)$} & Large & - & - & & \\
\hline & Medium & 148 & 88 & $7.7 \pm 3.5$ & $69.4 \%$ \\
\hline & Small & 185 & 143 & & \\
\hline \multirow[t]{3}{*}{ Dominance $(n=30)$} & Large & 30 & 7 & & \\
\hline & Medium & 39 & 20 & $4.9 \pm 2.1$ & $50.7 \%$ \\
\hline & Small & 223 & 121 & & \\
\hline
\end{tabular}




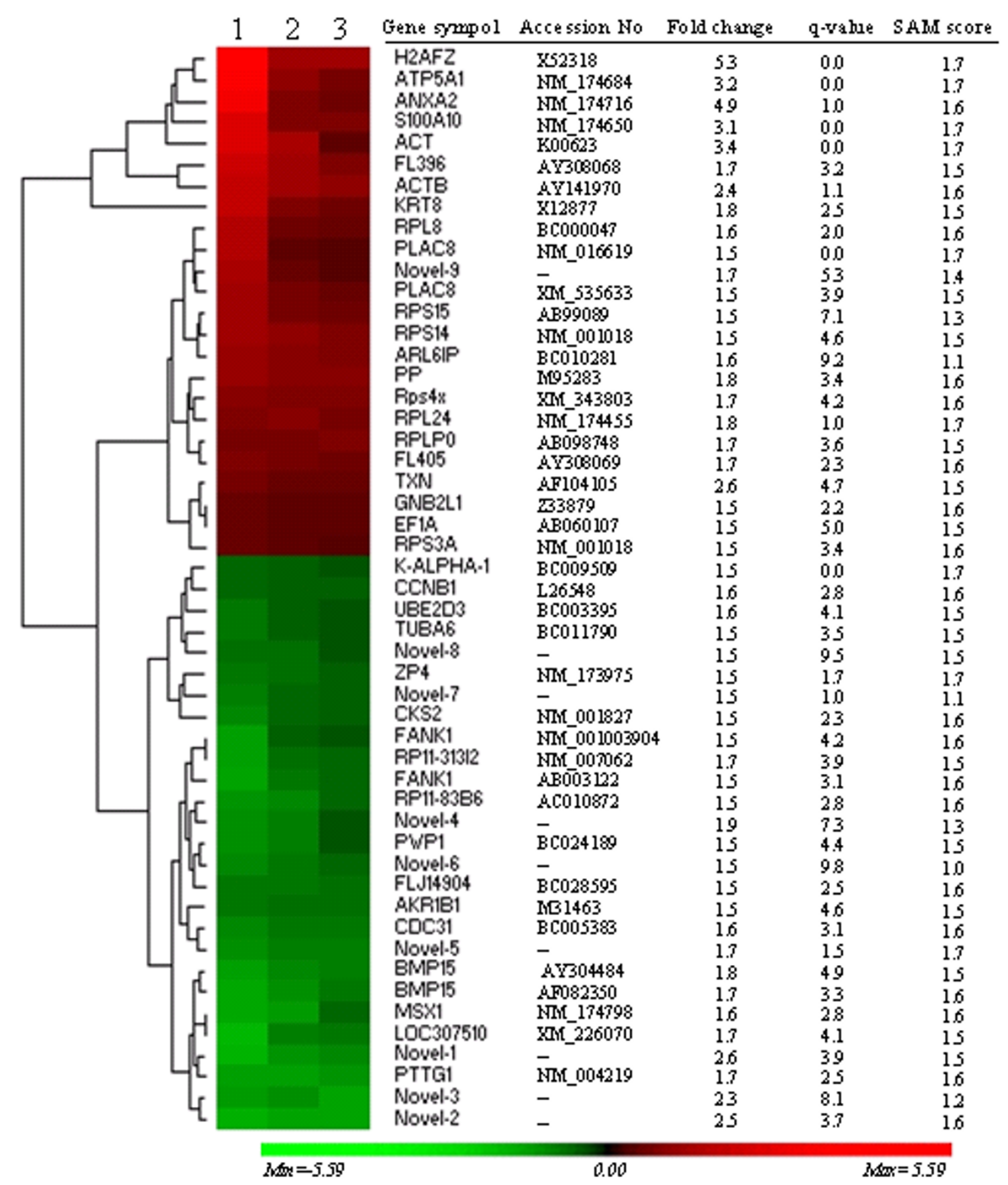

Figure 2

Hierarchical clustering and heatmap of $5 \mathrm{I}$ differentially expressed genes. The red blocks represent up-regulated genes while the green blocks represent down-regulated genes in oocytes recovered at growth phase.

(.)inorganic diphosphatase (PP) and thiol-disulfide exchange intermediate (TXN). On the other hand, oocytes recovered at dominance phase (Tab. 3) were encoded transcripts controlling transcription (MSX1, PTTG1, FANK1 and PWP1), cell cycle (CCNB1, CKS2, UBE2D3 and CDC31), aldehyde reductase activity (AKR1B1), 
Table 2: Transcripts up-regulated in oocytes recovered at growth phase compared to dominance phase

\begin{tabular}{|c|c|c|c|}
\hline Gene name & Accession No in NBCl GenBank & Fold change & Gene function \\
\hline $\begin{array}{l}\text { Bos taurus beta-actin mRNA } \\
\text { complete cds (ACTB) }\end{array}$ & AY 141970 & 2.4 & $\begin{array}{l}\text { Structural constituent of } \\
\text { cytoskeleton }\end{array}$ \\
\hline Bovine actin mRNA $3^{\prime}$ end (ACT) & $\underline{\mathrm{K} 00623}$ & 3.4 & $\begin{array}{l}\text { Structural constituent of } \\
\text { cytoskeleton }\end{array}$ \\
\hline $\begin{array}{l}\text { Bovine mRNA for histone } \\
\text { (H2AFZ) }\end{array}$ & $\times 52318$ & 5.3 & Chromosome organization \\
\hline $\begin{array}{l}\text { Bovine mRNA fragment for } \\
\text { cytokeratin A (no. 8) (KRT8) }\end{array}$ & $\underline{X 12877}$ & 1.8 & $\begin{array}{c}\text { Cytoskeleton organization and } \\
\text { biogenesis }\end{array}$ \\
\hline $\begin{array}{l}\text { Bos taurus } S 100 \text { calcium-binding } \\
\text { protein AIO mRNA (SI00A I0) }\end{array}$ & NM 174650 & 3.1 & Calcium ion binding \\
\hline $\begin{array}{l}\text { Bos taurus annexin A2 mRNA } \\
\text { (ANXA2) }\end{array}$ & NM 174716 & 4.9 & Calcium ion binding \\
\hline $\begin{array}{l}\text { Bos taurus ATP synthase, } \mathrm{H}+ \\
\text { transporting, mitochondrial FI } \\
\text { complex (ATP5AI) }\end{array}$ & NM 174684 & 3.2 & ATP binding \\
\hline $\begin{array}{l}\text { Bos taurus isolate FL } 396 \\
\text { mitochondrion partial genome }\end{array}$ & AY308068 & 1.7 & $\begin{array}{c}\text { NADH dehydrogenase } \\
\text { (ubiquinone) activity NADH } \\
\text { dehydrogenase (ubiquinone) } \\
\text { activity }\end{array}$ \\
\hline $\begin{array}{l}\text { Bos taurus isolate FL } 405 \\
\text { mitochondrion, partial genome }\end{array}$ & AY308069 & 1.7 & Structural constituent of ribosome \\
\hline $\begin{array}{l}\text { Bos taurus ribosomal protein L24 } \\
\text { mRNA (RPL24) }\end{array}$ & NM 174455 & 1.8 & Structural constituent of ribosome \\
\hline $\begin{array}{l}\text { Rattus norvegicus ribosomal } \\
\text { protein S4, X-linked mRNA } \\
\text { (Rps4x) }\end{array}$ & $\underline{X M \quad 343803}$ & 1.7 & Structural constituent of ribosome \\
\hline $\begin{array}{l}\text { Homo sapiens ADP-ribosylation } \\
\text { factor-like } 6 \text { interacting protein } \\
\text { (ARL6IP) }\end{array}$ & $\mathrm{BC} 010281$ & 1.6 & Structural constituent of ribosome \\
\hline $\begin{array}{l}\text { Bos taurus mRNA for similar to } \\
\text { acidic ribosomal phosphoprotein } \\
\text { PO (RPLP0) }\end{array}$ & $\mathrm{AB} 098748$ & 1.7 & Structural constituent of ribosome \\
\hline $\begin{array}{l}\text { Homo sapiens ribosomal protein } \\
\text { L8, mRNA (cDNA clone } \\
\text { IMAGE:3504599) (RPL8) }\end{array}$ & $\underline{\mathrm{BC} 000047}$ & 1.6 & Structural constituent of ribosome \\
\hline $\begin{array}{l}\text { Bos taurus mRNA for similar to } \\
\text { ribosomal protein S3a, partial cds } \\
\text { (RPS3A) }\end{array}$ & AB099017 & 1.5 & Structural constituent of ribosome \\
\hline $\begin{array}{l}\text { Bos taurus mRNA for similar to } \\
\text { ribosomal protein SI4, partial cds } \\
\text { (RPSI4) }\end{array}$ & AB099089 & 1.5 & Structural constituent of ribosome \\
\hline $\begin{array}{l}\text { Homo sapiens ribosomal protein } \\
\text { SI } 5 \text { mRNA (RPSI5) }\end{array}$ & NM 001018 & 1.5 & $\begin{array}{c}\text { Translation elongation factor } \\
\text { activity }\end{array}$ \\
\hline $\begin{array}{l}\text { Bos taurus mRNA for elongation } \\
\text { factor I alpha, complete cds } \\
\text { (EFIA) }\end{array}$ & AB060107 & 1.5 & $\begin{array}{l}\text { Inorganic diphosphatase, } \\
\text { Phosphatase }\end{array}$ \\
\hline $\begin{array}{l}\text { Bovine inorganic pyrophosphatase } \\
\text { mRNA sequence (PP) }\end{array}$ & M95283 & 1.8 & $\begin{array}{l}\text { Thiol-disulfide exchange } \\
\text { intermediate activity }\end{array}$ \\
\hline $\begin{array}{l}\text { Bos taurus thioredoxin mRNA } \\
\text { complete cds (TXN) }\end{array}$ & $\underline{\mathrm{AF} 104105}$ & 2.6 & Signal transduction \\
\hline $\begin{array}{l}\text { S.scrofa mRNA encoding G-beta } \\
\text { like protein (GNB2LI) }\end{array}$ & $\underline{Z 33879}$ & 1.5 & Unknown \\
\hline $\begin{array}{l}\text { Homo sapiens placenta-specific } 8 \\
\text { mRNA (PLAC } 8 \text { ) }\end{array}$ & NM 016619 & 1.5 & Unknown \\
\hline $\begin{array}{l}\text { PREDICTED: Canis familiaris } \\
\text { similar to Placenta-specific gene } 8 \\
\text { ((PLAC8) }\end{array}$ & XM 535633 & 1.5 & \\
\hline
\end{tabular}

Differentially expressed genes were identified by SAM at a false discovery rate (FDR) of $\leq 10 \%$ and $P<0.05$. 
Table 3: Transcripts down-regulated in oocytes recovered at growth phase compared to dominance phase

\begin{tabular}{|c|c|c|c|}
\hline Gene name & Accession $\mathrm{No}$ in NBCl GenBank & Fold Change & Gene function \\
\hline $\begin{array}{l}\text { Bos taurus bone Morphogenetic } \\
\text { protein I5 mRNA partial cds } \\
\text { (BMPI5) }\end{array}$ & AY304484 & 1.8 & Growth factor activity \\
\hline $\begin{array}{l}\text { Homo sapiens bone } \\
\text { morphogenetic protein I5 } \\
\text { precursor gene (BMPI5) }\end{array}$ & $\underline{\text { AF082350 }}$ & 1.7 & Growth factor activity \\
\hline $\begin{array}{l}\text { Bos taurus msh homeo box } \\
\text { homolog I (Drosophila) mRNA } \\
\text { (MSXI) }\end{array}$ & NM 174798 & 1.6 & Transcription factor activity \\
\hline $\begin{array}{l}\text { Homo sapiens pituitary tumor- } \\
\text { transforming gene I mRNA } \\
\text { (PTTGI) }\end{array}$ & NM 004219 & 1.7 & Transcription factor activity \\
\hline $\begin{array}{l}\text { Homo sapiens fibronectin type } 3 \\
\text { and ankyrin repeat domains I } \\
\text { mRNA (FANKI) }\end{array}$ & BC024I89 & 1.5 & Transcription factor activity \\
\hline $\begin{array}{l}\text { Bos taurus fibronectin type } 3 \text { and } \\
\text { ankyrin repeat domains I (FANKI) }\end{array}$ & NM 001003904 & 1.5 & Transcription factor activity \\
\hline $\begin{array}{l}\text { Homo sapiens nuclear } \\
\text { phosphoprotein similar to } \mathrm{S} . \\
\text { cerevisiae (PWPI) }\end{array}$ & NM 007062 & 1.5 & Cell growth and/or transcription \\
\hline $\begin{array}{l}\text { Homo sapiens } C D C 28 \text { protein } \\
\text { kinase regulatory subunit } 2 \text { mRNA } \\
\text { (CKS2) }\end{array}$ & NM 001827 & 1.5 & Cell cycle \\
\hline $\begin{array}{l}\text { Bos taurus mRNA sequence } \\
(\mathrm{CCNBI})\end{array}$ & $\underline{\mathrm{L} 26548}$ & 1.6 & $\begin{array}{l}\text { Regulation of cell cycle } \\
\text { progression }\end{array}$ \\
\hline $\begin{array}{l}\text { Homo sapiens centrin, EF-hand } \\
\text { protein, } 3 \text { (CDC3I homolog, } \\
\text { yeast) }\end{array}$ & BC005383 & 1.6 & Mitotic centrosome separation \\
\hline $\begin{array}{l}\text { Homo sapiens ubiquitin- } \\
\text { conjugating enzyme E2D } 3 \text { (UBC4/ } \\
5 \text { homolog) (UBE2D3) }\end{array}$ & $\underline{\mathrm{BC} 003395}$ & 1.6 & $\begin{array}{l}\text { Ubiquitin conjugating enzyme } \\
\text { activity }\end{array}$ \\
\hline $\begin{array}{l}\text { Homo sapiens tubulin, alpha, } \\
\text { ubiquitous, mRNA (cDNA clone } \\
\text { MGC:4689) (K-ALPHA-I) }\end{array}$ & BC009509 & 1.5 & Nucleotide binding \\
\hline $\begin{array}{l}\text { Homo sapiens tubulin alpha 6, } \\
\text { mRNA (cDNA clone MGC:1 9827) } \\
\text { (TUBA6) }\end{array}$ & $\underline{\mathrm{BCO} O 11790}$ & 1.5 & Nucleotide binding \\
\hline $\begin{array}{l}\text { Bovine aldose reductase mRNA 3' } \\
\text { end (AKRIBI) }\end{array}$ & M31463 & 1.5 & Aldehyde reductase activity \\
\hline $\begin{array}{l}\text { Bos taurus zona pellucida } \\
\text { glycoprotein } 4 \text { mRNA (ZP4) }\end{array}$ & NM 173975 & 1.5 & Binding of sperm to zona pellucida \\
\hline $\begin{array}{l}\text { Rattus norvegicus similar to } \\
\text { putative nuclear protein } \\
\text { (LOC3075I0) }\end{array}$ & $\underline{X M \quad 226070}$ & 1.7 & Unknown \\
\hline $\begin{array}{l}\text { Homo sapiens genomic DNA, } \\
\text { chromosome II q, (clone:RPII- } \\
3|3| 2 \text { ) }\end{array}$ & $\underline{\mathrm{AP} 003122}$ & 1.7 & Unknown \\
\hline $\begin{array}{l}\text { Homo sapiens BAC clone RPII- } \\
83 B 6 \text { from 2, complete sequence } \\
\text { (RPII-83B6) }\end{array}$ & $\underline{\mathrm{AC} 010872}$ & 1.5 & Unknown \\
\hline $\begin{array}{l}\text { Homo sapiens hypothetical } \\
\text { protein FLJI4904, mRNA (cDNA } \\
\text { clone) (FLJ14904) }\end{array}$ & $\underline{\mathrm{BC} 028595}$ & 1.5 & Unknown \\
\hline
\end{tabular}

Differentially expressed genes were identified by SAM at a false discovery rate (FDR) of $\leq 10 \%$ and $P<0.05$.

nucleotide binding (TUBA6 and K-ALPHA-1), growth fac- tially regulated transcripts. No differences in relative tor (BMP15) and fertilization (ZP4).

\section{Real-time PCR Validation}

Real-time PCR analysis using independent oocyte samples was conducted to validate the array results of 10 differenabundance of the internal control gene (GAPDH) were observed in all samples. Based on this, the quantitative real-time PCR has confirmed the relative abundance of 8 transcripts $(80 \%)$ to be in agreement with microarray results (Fig. 4A, B, C). The mRNA relative abundance of 


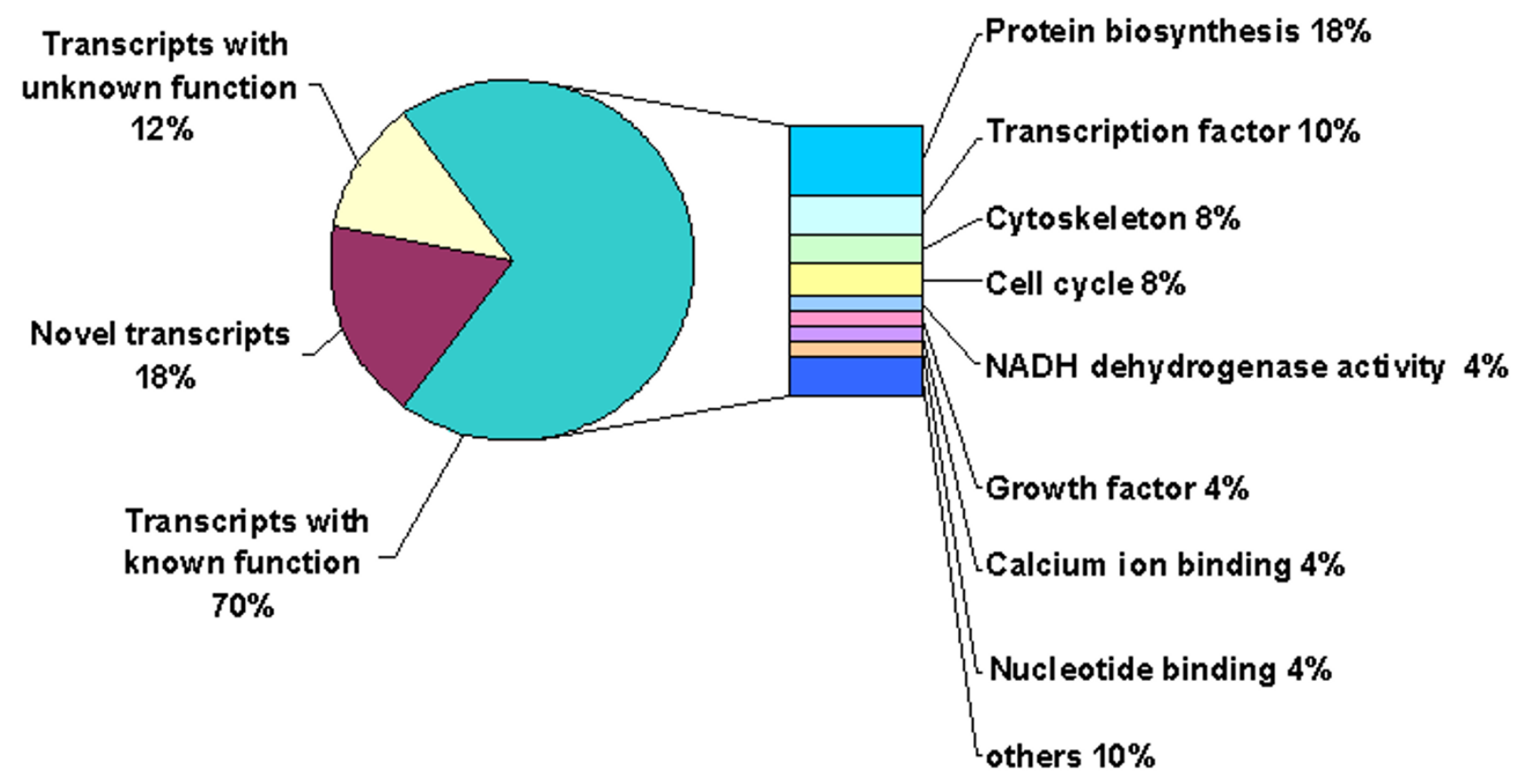

Figure 3

Differentially expressed genes as classified based on the Gene Ontology Consortium classifications [29].

mRNAs for ANAXA2, S100A10, RPL24, and PP was higher $(P<0.05)$ in growth phase compared to dominance phase oocytes. Greater transcript abundance for MSX1 and BMB15 was observed in dominance phase versus growth phase oocytes. However, differences in transcript abundance of FL396 and PTTG1 between the two oocyte groups were not statistically significant. The array results of CKS2 and CCNB1 could not be confirmed by real-time quantitative PCR (Fig. 4A).

\section{Quantitative analysis of selected transcripts in cumulus cells}

To avoid any biasness in the number of cumulus cells used as an input for mRNA isolation and subsequent realtime PCR, cumulus cells were derived from equal number of cumulus oocyte complexes (COCs) with similar morphological appearance. After mRNA isolation and subsequent cDNA synthesis, the relative abundance of GAPDH gene was tested and showed no variation between these samples. Two transcripts (MSX1 and FL396) were highly abundant $(P<0.05)$ in cumulus cells of dominance phase than that of growth phase (Fig. 5). On the other hand, RPL24 and CKS2 transcripts were found to be more abundant in cumulus cells of growth phase compared to that of dominance phase. The relative abundance of mRNA for S100A10 was nearly the same in cumulus cells of both phases.

\section{Validation of relationship between transcript abundance} and oocyte competence using BCB staining

Immature oocytes screened for developmental competence based on BCB staining were used for validation of the expression profile of five transcripts (BMP15, RPL24, PP, MSX1 and PTTG1). The cDNA synthesized from BCB ${ }^{+}$ (stained blue) and $\mathrm{BCB}^{-}$(stained colourless) oocyte samples were quantified using real-time PCR. After confirming that there were no significant differences in the relative abundance of GAPDH between the samples, all transcripts were quantified using independent real-time PCR runs. The relative abundance for MSX1 and PTTG1 were higher $(P<0.05)$ in $\mathrm{BCB}^{-}$oocytes than $\mathrm{BCB}^{+}$ones (Fig. 6$)$. The BMP15 was also more abundant in $\mathrm{BCB}^{-}$than $\mathrm{BCB}^{+}$ oocytes but differences were not significant. On the other hand, greater mRNA abundance $(P<0.05)$ for RPL24 and $\mathrm{PP}$ has been observed in $\mathrm{BCB}^{+}$than $\mathrm{BCB}^{-}$oocytes (Fig. 6). 

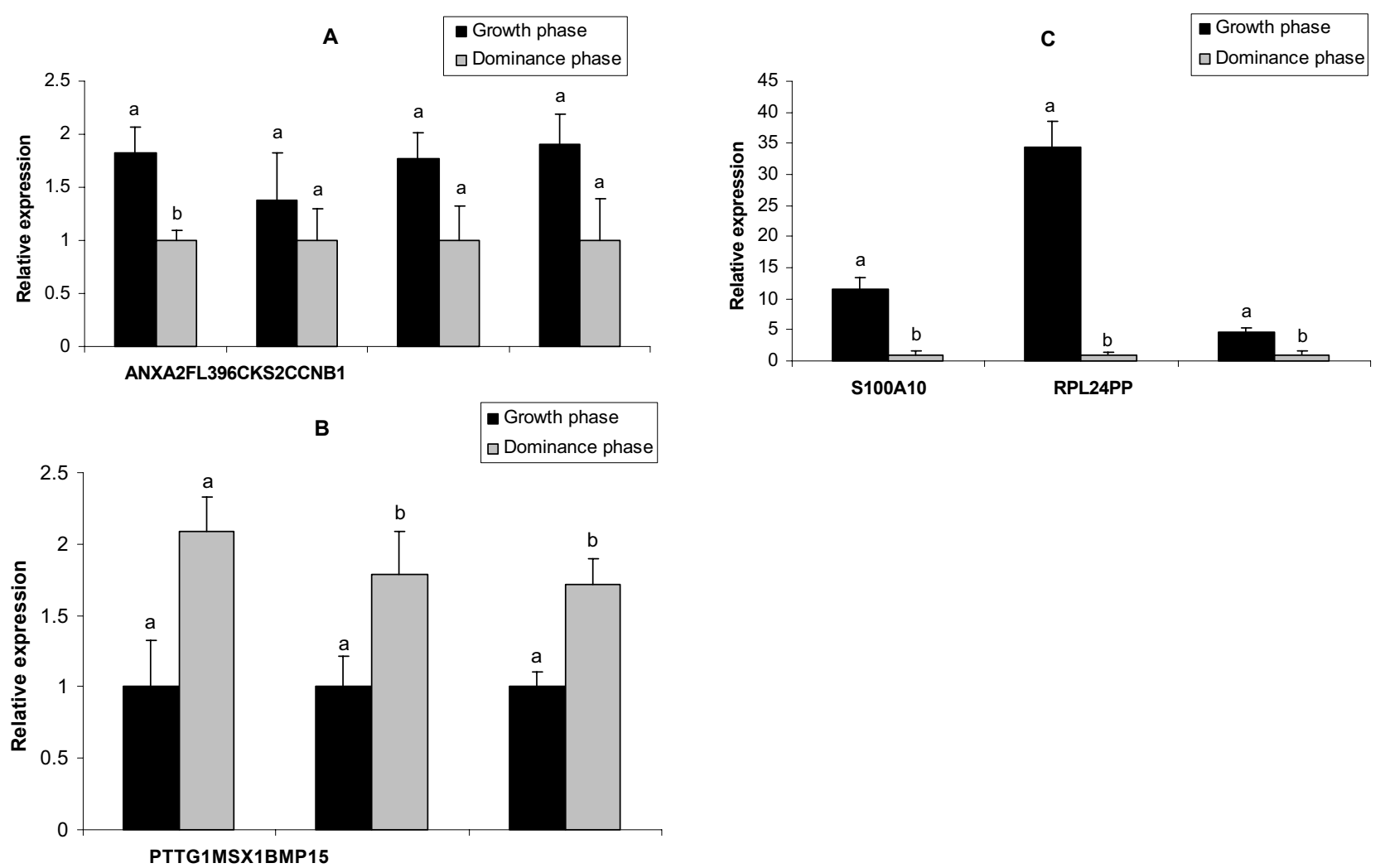

Figure 4

Quantitative real-time PCR validation of 10 differentially expressed genes in bovine oocytes recovered at growth phase (day 3) vs. dominance phase (day 7$)$ as identified by microarray analysis $(A, B, C)$. The relative abundance of mRNA levels represents the amount of mRNA compared to the calibrator (with the lowest normalized value). Bars with different superscripts (a, b) are significantly different at $P<0.05$.

\section{Localization of bovine MSXI mRNA and protein}

Immunofluorescent labelling of MSX1 gene in ovarian samples collected at the time of estrus (day 0), ovulation (day 1), growth phase (day 3 ) and dominance phase (day 7) showed the presence of this protein in all stages of follicular development under investigation. More specifically, this protein was found to be more localized in the oocyte cytoplasm than the enclosed cumulus cells (Fig. $7 \mathrm{~d}, \mathrm{~h}, \mathrm{p}$ ) or other cellular layers of the growing follicle (Fig. 7b, f, n) at all stages of follicular development except at growth phase (Fig. 7j, l). Furthermore, MSX1 protein was found to be dispersed in the cytoplasm of immature and matured oocytes and early zygote (Fig. 8a, b, c) but tends to be localized around the nucleus at advanced zygote, 2-cell, 4-cell and 8-cell embryos (Fig. 8d, e, f, g). Comparative analysis of protein signals between oocytes showed that green fluorescence signals were reduced after maturation (Fig. 8b). Moreover, in situ hybridization experiment showed that MSX1 mRNA was localized in the oocytes, cumulus cells and follicular wall throughout all stages of follicular turnover (Fig. 9A, B, C, D, E, F, G, H).

\section{Discussion}

Investigation on the molecular characteristics of oocytes of varying developmental competence is critical for the development of future classification criteria for the selection of oocytes with superior developmental capacity [31]. It has been shown that the molecular causes for poor developmental capacity of bovine oocytes may be highly complex and may be reliant on many small changes in the RNA levels of many genes [32]. However; our understanding of composition of the oocyte transcriptome and the identity of key oocyte-expressed genes with important regulatory roles in folliculogenesis and early embryonic development is far from complete [33]. Thus, our study mainly focuses on identifications of differences in mRNA transcript abundance which may be associated with developmental competence of bovine oocytes using cDNA microarray as a functional genomics approach. 


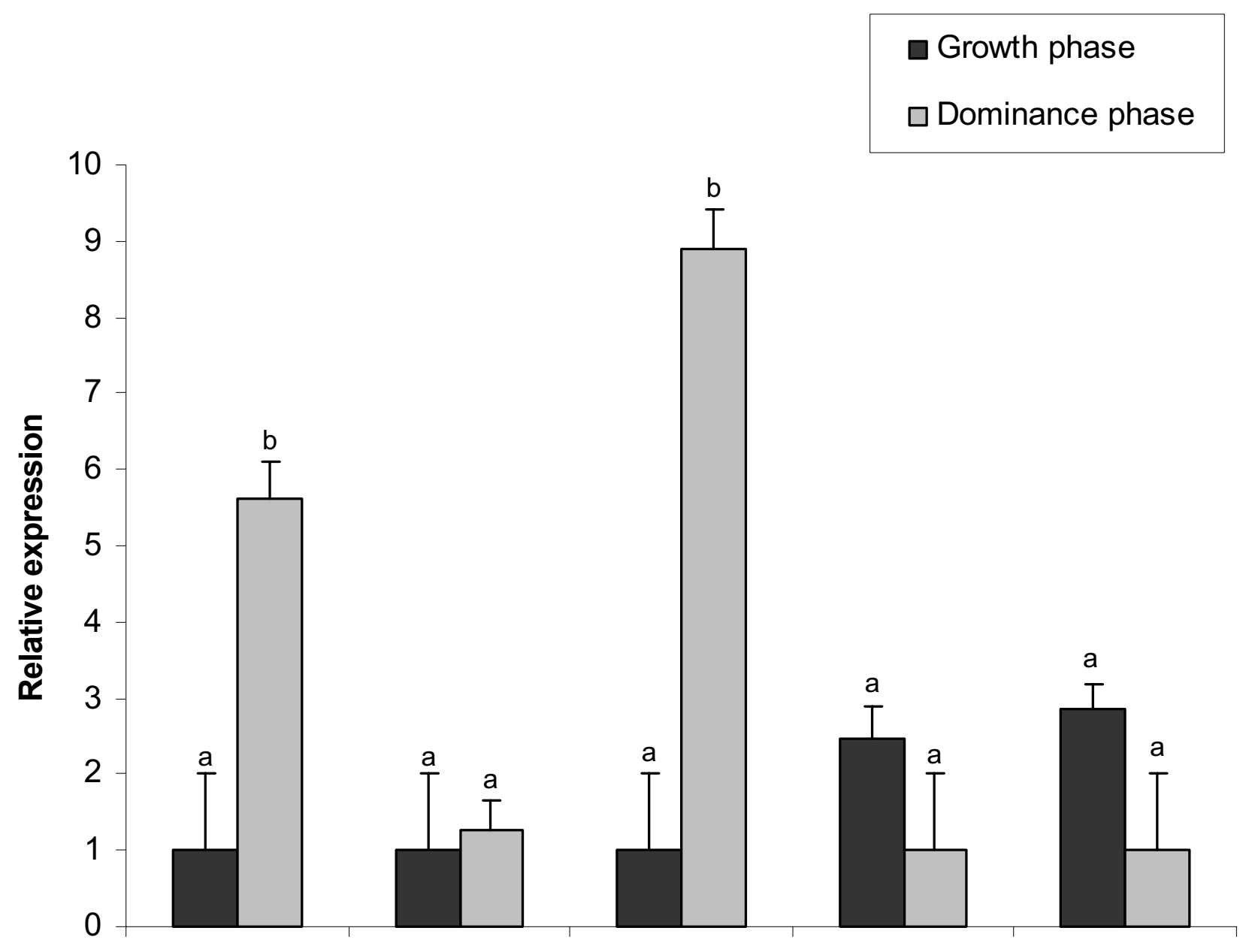

FL396S100A10MSX1CKS2RPL24

\section{Figure 5}

Quantitative real-time PCR of 5 genes in bovine cumulus cells denuded from oocytes recovered at growth phase (day 3 ) vs. dominance phase (day 7). The relative abundance of mRNA levels represents the amount of mRNA compared to the calibrator (with the lowest normalized value). Bars with different superscripts $(\mathrm{a}, \mathrm{b})$ are significantly different at $P<0.05$.

Growing oocytes have higher rate of transcription and translation resulting in the formation of RNAs and proteins both for oocyte growth and storage [34]. The previous molecules could be redirected to fulfil new tasks as resumption of meiosis [35] and regulating maternal to zygotic transition [36]. Developmental competence of mammalian oocytes depends on high rates of RNA and protein synthesis, imprinting processes and biogenesis of organelles such as mitochondria [37]. Similarly, in the present study oocytes from the growth phase were found to be enriched with transcripts related to protein biosynthesis as compared to their dominance phase counterparts. An adequate pool of ribosomes, which were synthesized by transcription of the ribosomal RNA (rRNA) genes, is required for protein synthesis during oocyte growth and embryonic development. Failure to detect one or all of ribosomal RNA (rRNA) genes during oocyte growth or later during interphase of the first cell cycle is an indicator of developmental incompetence [38]. This is in agreement with our results that showed the down-regulation of RPL24 transcript in oocytes from dominance phase with low developmental potential and could be validated using BCB screened oocytes. This may suggest that there is an optimal threshold of mRNA transcript abundance for ribosomal RNA genes below which the developmental competence of the oocytes is compromised.

Various transcription factors are known to be present in the maternal mRNA store until their recruitment for translation at the time of maternal-embryonic transition [39]. In the present study, different transcription factors (MSX1, 

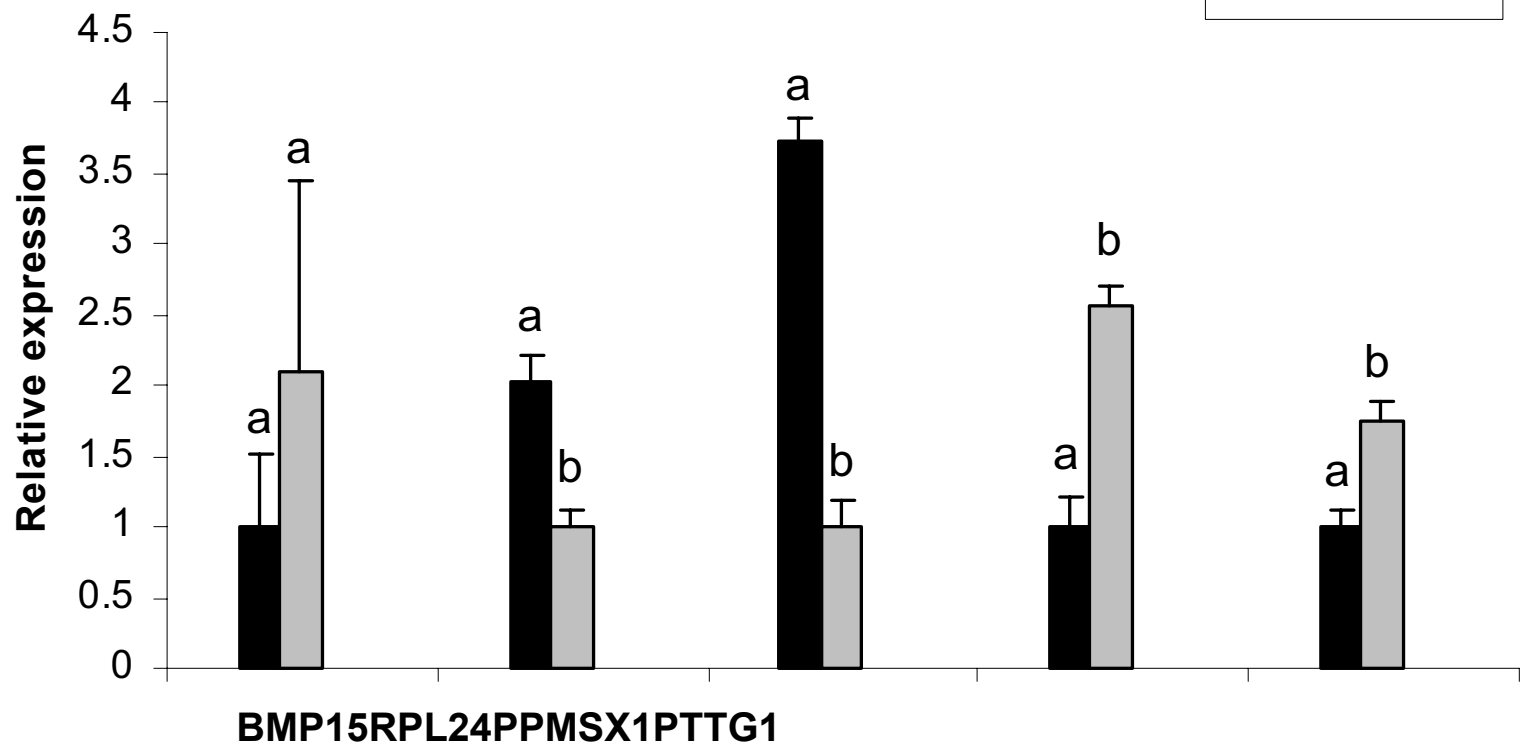

\section{Figure 6}

Quantitative real-time PCR of 5 genes in bovine oocytes treated with brilliant cresyl blue stain [BCB- (colourless cytoplasm, increased G6PDH activity) and BCB+ (coloured cytoplasm, low G6PDH activity)]. The relative abundance of mRNA levels represents the amount of mRNA compared to the calibrator (with the lowest normalized value). Means without common superscripts $(a, b)$ were considered to be significantly different at $P<0.05$.
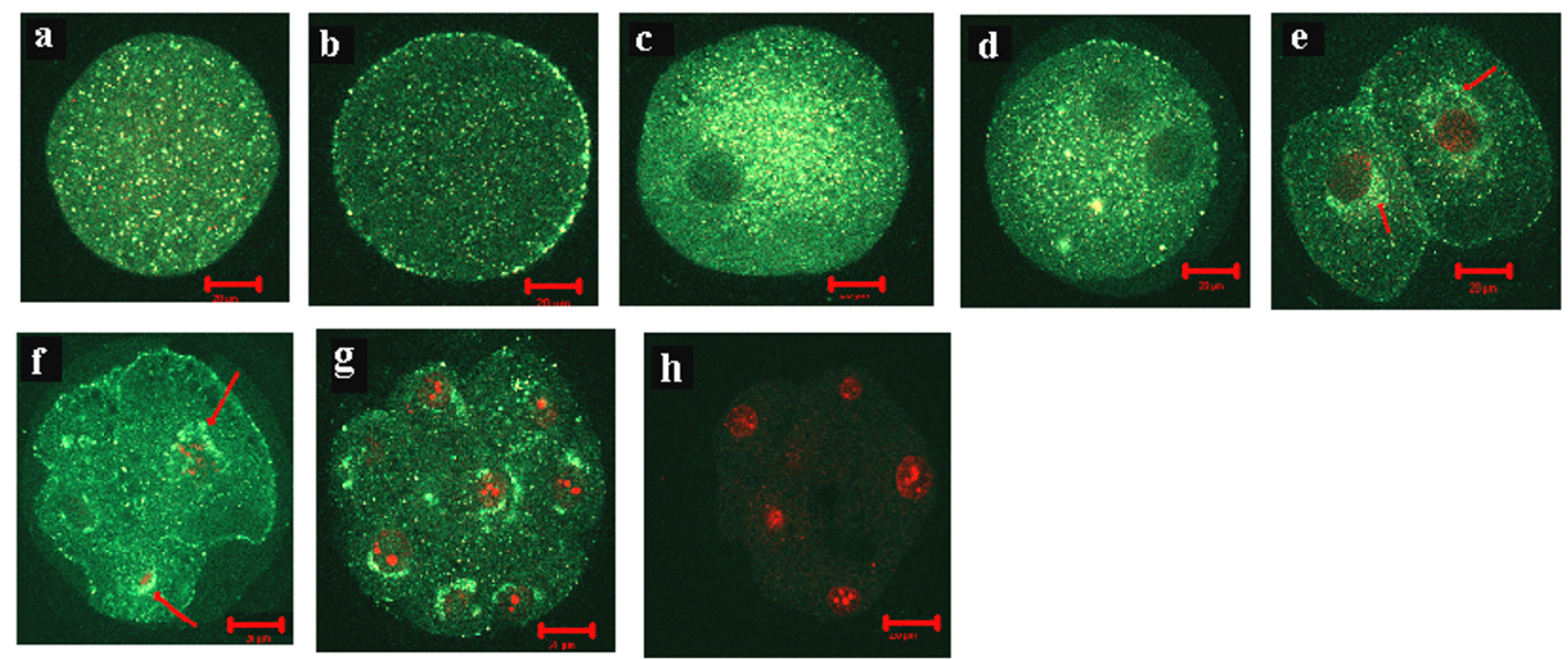

Figure 8

Subcellular localization of bovine MSXI protein in bovine oocytes and early cleavage embryonic stages [immature oocyte (a), matured oocyte (b), zygote (c), advanced zygote (d), 2-cell (e), 4-cell (f) and 8-cell (g)]. Negative control (h) was processed without addition of primary anti-MSXI antibody. Nuclei are stained with propidium iodide (red). Scale bars represent $20 \mu \mathrm{m}$. 
Lower magnification

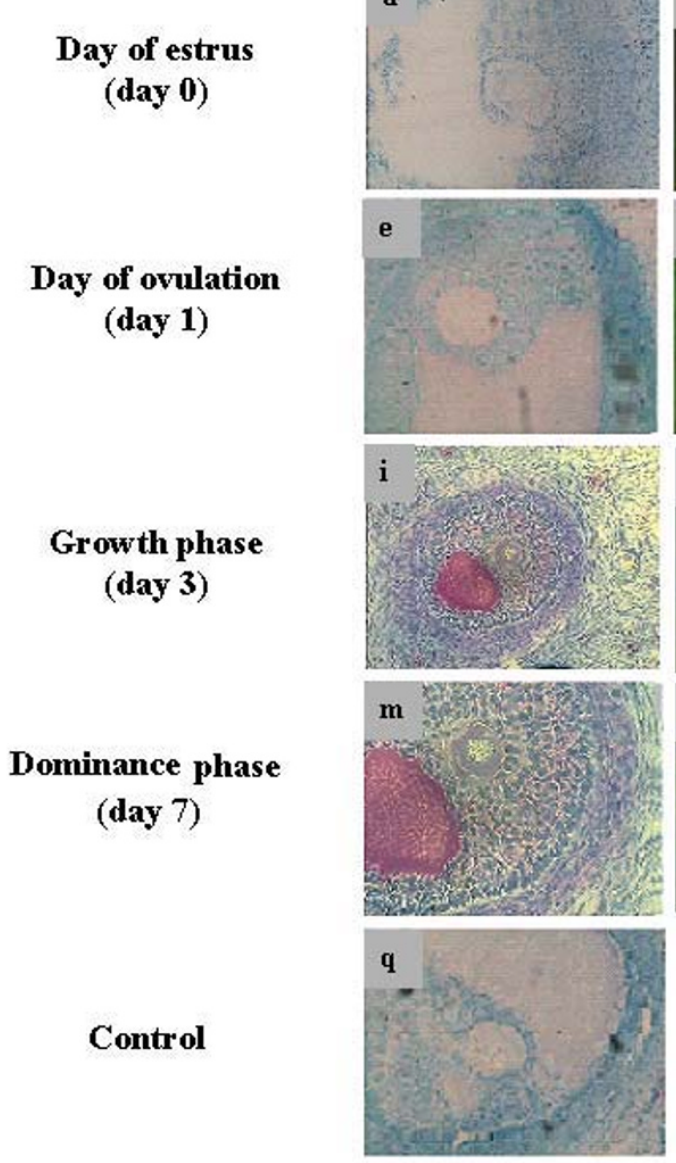

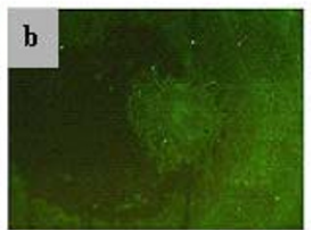
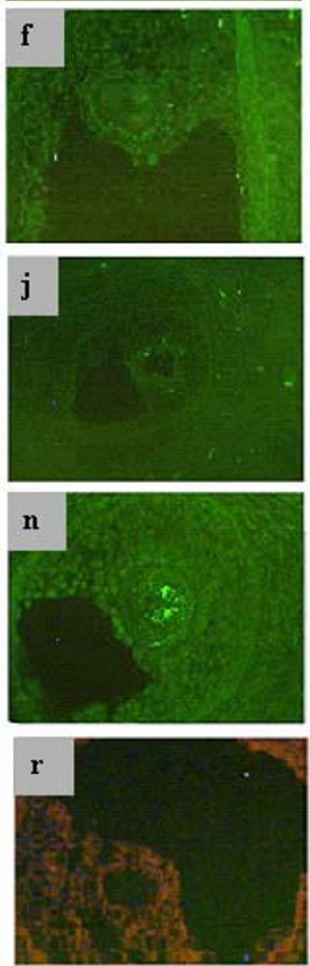

Higher magnification
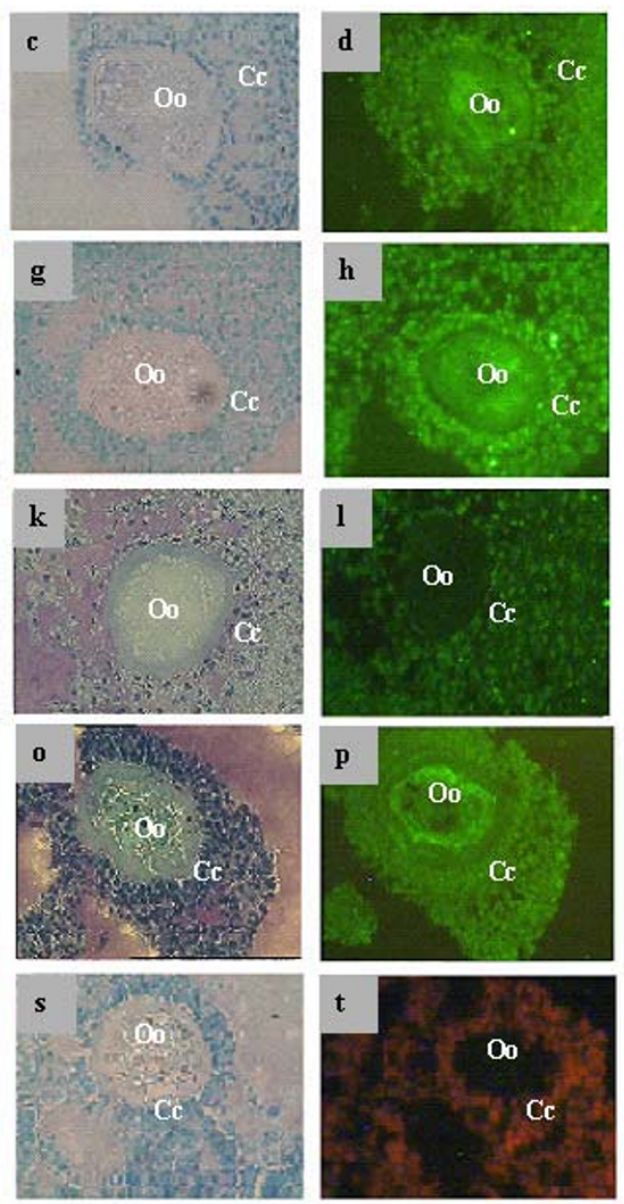

\section{Figure 7}

Immunohistochemical localisation of MSXI protein in bovine ovarian sections at day of estrus (b, d), day of ovulation (f, h), growth phase $(j, I)$, dominance phase $(m, q)$. Cumulus cells are marked with $C c$ and oocytes are marked with Oo. Negative controls were processed without addition of primary anti-MSXI antibody $(r, t)$. Sections were counterstained with toluidine blue (a, c, e, g, i, k, m, o, q and s). Images from the same ovarian sections were captured with lower and higher magnification.

TG1, FANK1 and PWP1) were found to be up-regulated in dominance phase compared to growth phase oocytes. MSX gene families encode homeodomain transcription factors [40] and their protein products control key developmental processes such as differentiation and patterning during early development [41]. Overexpression of the MSX1 suppresses cell growth and cell cycle progression in human ovarian cancer cell line by regulating the expression of key cell cycle regulators [42]. In addition, MSX1 has been reported to regulate the p53 tumor suppressor protein in human tumours and thereby enhances apoptosis mediated suppression of p53 [43]. Moreover, mice MSX1 homozygous mutants die at birth [44]. In a recent study, MSX1 was more abundant in oocytes with reduced development competence [31].

Pituitary tumor transforming gene (PTTG1) was isolated from a pituitary tumor cell line and its over-expression results in cellular transformation in vitro and tumor formation in nude mice [45]. Moreover, this gene stimulates expression of the Bax gene, which induces apoptosis in human embryonic kidney cell line [46]. Consistent with the previous facts, the enrichment of dominance phase oocytes with apoptotic related genes (MSX1 and PTTG1) may be related to the level of atresia in subordinate follicles as influenced by the dominant follicle which may 


\section{Lower magnification Higher magnification}
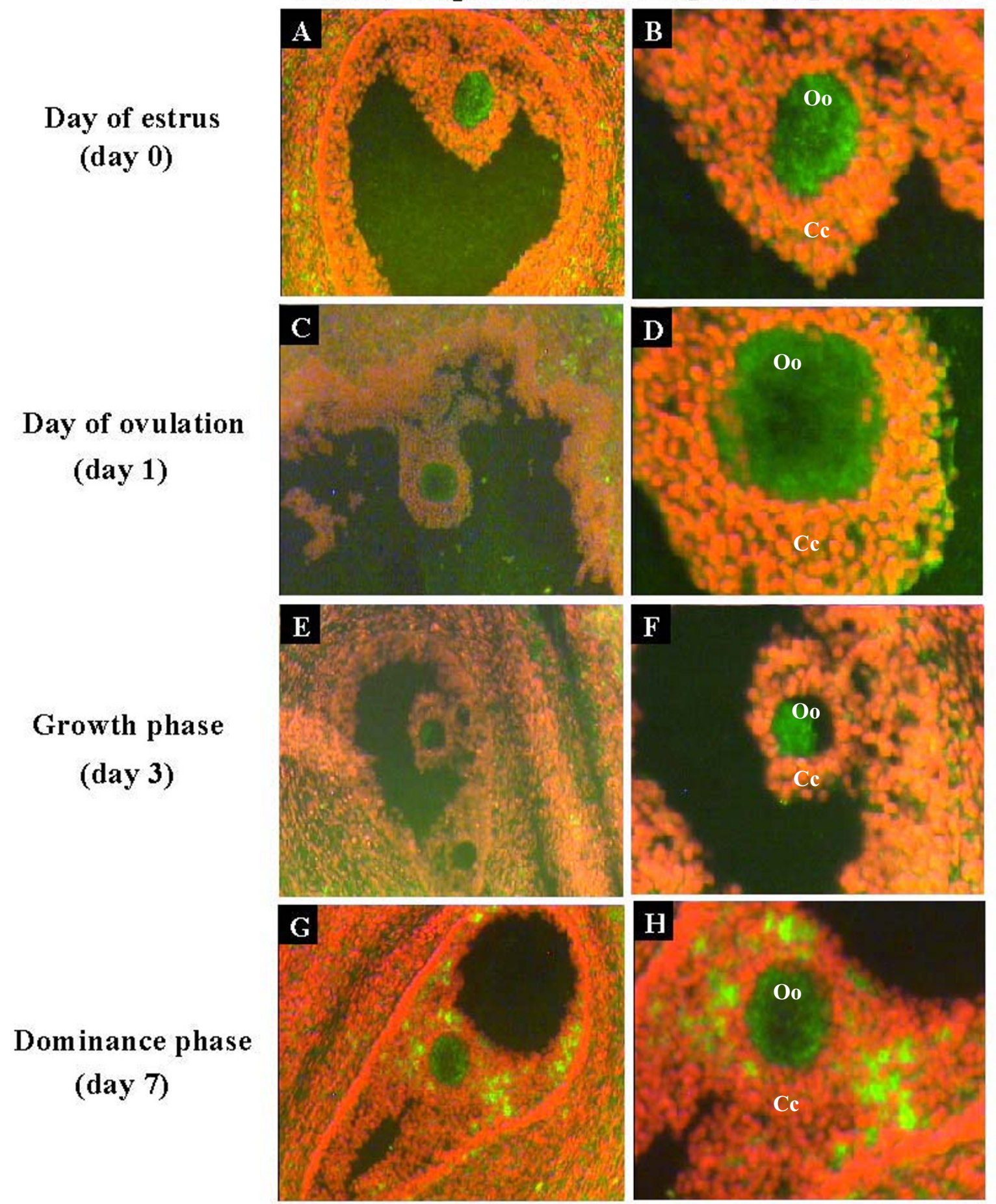

Figure 9

Fluorescent in situ hybridization of MSXI mRNA conducted with DIG labelled RNA antisense probe in bovine ovarian sections at day of estrus $(A, B)$, day of ovulation $(B, C)$, growth phase $(D, E)$, dominance phase $(F, G)$. Cytoplasms of the oocytes $(O o)$ are darkly stained with green fluorescent compared to cumulus cells $(\mathrm{Cc})$. Negative controls were hybridized with DIG labelled RNA sense probe $(\mathrm{H}, \mathrm{I})$. Images from the same ovarian sections were captured with lower and higher magnification. 
lead to reduced developmental capacity of enclosed oocytes. In a recent study conducted in our laboratory, MSX1 and PTTG1 were found to be up-regulated in embryo biopsies derived from blastocysts which resulted in no pregnancy after transfer to recipients [25].

Optimal expression of MSX1 as transcription factor seems to be important for cellular physiology $[26,27]$. In the present study, the MSX1 protein was detected in all follicular compartments of the growing follicle at different stages of follicular turnover and early preimplantation stages, with a slight decrease in fluorescent intensity in ovaries at growth phase. As embryonic development proceeds there is accumulation of the MSX1 protein around the nucleus of the blastomeres which is consistent with the localization of homeobox gene family namely $\mathrm{cdx} 2$ in mouse embryos [47]. Furthermore, mRNA for MSX1 was also distributed in all follicular layers with intensive signal in the oocytes. As a member of transcription factor gene, the possible role of MSX1 in regulating follicular turnover and early embryonic development needs further investigations.

Oocyte growth during folliculogenesis is regulated by granulosa cell derived proteins [48], which are in turn regulated by oocyte-derived factors [49]. In addition, cumulus cells provide nutrients for the oocyte and influence oocyte development in a paracrine fashion [50], and these paracrine factors contribute to induce meiotic resumption of oocytes [51]. Characterization of the signalling pathways driving changes in transcript abundance for co-regulated and differentially regulated genes in oocytes versus associated cumulus cells may lead to a better understanding of interdependent gene regulation between germ and somatic cells [52]. In this study, compared to other candidate transcripts the bovine MSX1 was found to be higher in both oocytes and the corresponding cumulus cells at dominance phase than those from growth phase. Therefore, this transcript can be considered as one of the factors activated in oocyte and cumulus cells from the subordinate follicles due to the presence of the dominant follicle. Similar studies $[53,54]$ have described the expression profile of some transcripts (cyclooxygenase-2, hyaluronic acid synthase-2, gremlin, and pentraxin-3) in the cumulus cells as potential markers of the quality of the enclosed oocyte.

The BCB staining was used effectively to select bovine oocytes for further developmental competence after in vitro fertilization [55] or somatic cell nuclear transfer [56]. Therefore, in the present study, BCB staining was used as an independent model to screen oocytes for their developmental competence in order to validate the differential expression of candidate genes identified in array analysis. Higher abundance of MSX1 and PTTG1 in dominance phase oocytes in array experiment was consistent with their higher abundant in $\mathrm{BCB}^{-}$oocytes than in $\mathrm{BCB}^{+}$ones. Similarly, the relatively higher abundance of RPL24 and PP transcripts in oocytes from growth phase was consistent with their higher abundance in $\mathrm{BCB}^{+}$oocytes. Thus, there is a clear association of mRNA abundance for genes detected in microarray experiment and developmental competence of oocyte tested with $\mathrm{BCB}$ staining. The bovine RPL24 and MSX1 as members of ribosomal proteins and transcription factor gene family, respectively can be considered as good markers of oocyte developmental competence, as they showed consistent results in both models.

\section{Conclusion}

The reported differences in developmental competence of bovine oocytes derived from small follicles at growth and dominance phases of follicular development are also accompanied by differences in the relative abundance of transcripts related to the various molecular events and processes regulating oocyte competence and follicular development. Our validation with an independent model for the relative abundance of some selected transcripts, supports the notion that many of the transcripts identified as differentially regulated and described here may represent marker candidate genes for oocyte developmental competence. However, the exact role of these transcripts in controlling oocyte developmental potential needs further investigation.

\section{Methods \\ Experimental animals, estrus synchronization and detection}

The experimental protocol was carried out according to the rules and regulations of the German law of animal protection.

Sixty Simmental cyclic heifers 24 to 30 months old, were selected based on general clinical examination and normal ovarian cyclicity as determined by ultrasound scanning. The animals were housed as one group and were fed grass silage ad libitum. Estrus and subsequent ovulation were synchronized by two administrations of prostaglandin PGF2 $\alpha$ (Estrumate, $2 \mathrm{ml}$ i.m, Fa. Essex, Germany) at 11 days interval followed by GnRH injection (Receptal, 2500 IU i.m, Intervet, Unterschleissheim, Germany) on the day of estrus onset. Estrus was detected after two days of the last prostaglandin PGF2 $\alpha$ treatment. Common signs of estrus were monitored by visual observation followed by careful palpation of ovaries for confirmation.

\section{Ovum pick up (OPU)}

OPU was performed at two different phases of follicular development during the first follicular wave using a total of 60 heifers at growth phase (day 3 after estrus, $n=30$ ) 
and dominance phase (day 7 after estrus, $\mathrm{n}=30$ ) for two sessions of OPU in each phase. The heifers were restrained in a chute, and given $5 \mathrm{ml}$ of epidural anesthesia (procaine hydrochloride $2 \%$, Selectavet, Munich, Germany). Using transvaginal ultrasound scanner (Pie Medical 400 Vet, Maastricht, Netherlands) with a $7.5 \mathrm{MHz}$ sector probe the follicles were visualized on the monitor and counted. The follicles were classified according to their size into three categories: small (3-5 mm), medium $(6-8 \mathrm{~mm})$ and large follicles $(\geq 9 \mathrm{~mm})$. A 50-cm-long 18-gauge needle was passed through a needle guide along the polyethylene housing of the transducer, and carried into the fornix vagina. After fixing the ovary against the transducer, the needle was advanced to puncture the vaginal wall to enter the ovarian follicle. The needle was attached via Teflon tubing to a 50-ml Falcon tube and vacuum pressure provided with a regulated vacuum pump (K-MAR-5000B; William Cook Europe) and adjusted to create a flow rate of $16-20 \mathrm{ml} / \mathrm{min}$. The follicular content of each heifer was aspirated individually into modified Parker maturation medium (MPMM) supplemented with $15 \%$ oestrus cow serum (OCS), $0.5 \mathrm{mM}$ L-glutamine, $0.2 \mathrm{mM}$ pyruvate, 50 $\mu \mathrm{g} / \mathrm{ml}$ gentamycin sulphate, $10 \mu \mathrm{l} / \mathrm{ml}$ FSH (Folltropin, Vetrepharm, Canada) and kept at $39^{\circ} \mathrm{C}$ in thermos. The follicular fluid contents were poured into a square grid dish to facilitate finding of oocytes under a stereomicroscope. The collected oocytes were kept in the same maturation medium used for collection before being separated from the surrounding cumulus cells. Oocytes from each follicular size category and phase were handled and frozen separately.

\section{Oocytes denudation and storage}

In this study, only COCs from the small follicles of the growth and dominance phases were used for the analysis of transcript abundance. Cumulus cells were removed from the oocytes of each phase mechanically in maturation medium supplemented with hyaluronidase $1 \mathrm{mg} / \mathrm{ml}$ (Sigma). Separation of cumulus cells was carefully checked under a stereomicroscope. Cumulus free oocytes and the corresponding cumulus cells of each phase were washed two times in PBS (Sigma) and snap frozen separately in cryo-tubes containing $20 \mu \mathrm{l}$ of lysis buffer [0.8\% IGEPAL (Sigma), $40 \mathrm{U} / \mu \mathrm{l}$ RNasin (Promega Madison WI, USA), $5 \mathrm{mM}$ dithiothreitol (DTT) (Promega Madison WI, USA)]. Finally, samples were stored at $-80^{\circ} \mathrm{C}$ until RNA extraction.

\section{RNA isolation from oocytes and cumulus cells}

Messenger RNA isolation of oocytes and cumulus cells was performed at four different points during the whole experiment. 1) A total of six pools, each containing 20 oocytes from growth and dominance phases of follicular development, were used for array analysis after amplification, 2) A total of six pools, each containing 20 oocytes from growth and dominance phases, were used for realtime validation of array results, 3) The cumulus cells detached from the oocytes at the growth and dominance phases were also used for mRNA isolation and subsequent expression analysis of selected transcripts, 4) A total of 8 pools of oocytes, each containing 50 oocytes from $\mathrm{BCB}^{+}$ and $\mathrm{BCB}$ - categories were used to validate the expression profile of selected transcripts in oocytes with different developmental competences. In all cases, mRNA isolation was performed using Dynabead oligo (dT)25 (Dynal Biotech, Oslo, Norway) according to manufacturer's instructions. Briefly, oocytes or cumulus cells in lysis buffer were mixed with $40 \mu \mathrm{l}$ binding buffer $[20 \mathrm{mM}$ Tris $\mathrm{HCl}$ with $\mathrm{pH}$ 7.5, $1 \mathrm{M} \mathrm{LiCl}, 2 \mathrm{mM}$ EDTA with pH 8.0] and incubated at $70^{\circ} \mathrm{C}$ for $5 \mathrm{~min}$ to obtain complete lysis of and to release RNA. Ten microlitres of oligo (dT) 25 attached magnetic bead suspension were added to the samples, and incubated at room temperature for $30 \mathrm{~min}$. The hybridized mRNA and magnetic beads were washed three times using washing buffer (10 mM Tris HCL with $\mathrm{pH} 7.5,0.15 \mathrm{mM}$ $\mathrm{LiCl}, 1 \mathrm{mM}$ EDTA with $\mathrm{pH}$ 8.0). For each sample, cDNA synthesis has been performed using oligo (dT)23 primer and superscript reverse transcriptase II (Invitrogen, Karlsruhe, Germany) except for samples used in array analysis where the reverse transcription was performed using T7 promotor attached oligo $\mathrm{d}(\mathrm{T}) 21$ primer.

\section{RNA amplification}

First and second-strand cDNA synthesis were carried out as described in our previous study [25]. Ten amplification cycles were used during second strand synthesis as this showed less bias on the representativeness of the original mRNA population after in vitro transcription [57]. The cDNA was purified and used for in vitro transcription using AmpliScribe T7 transcription kit (Epicentre technologies, Oldendorf, Germany) according to manufacturer's instructions. Then the amplified RNA (aRNA) was purified using RNeasy Mini kit (Qiagen, Hilden, Germany) according to the manufacturer's recommendations. Finally, the aRNA was eluted in $30 \mu \mathrm{l}$ RNase free water from which $8 \mu \mathrm{l}$ was taken to estimate the yield, purity of aRNA by gel electrophoresis and UV absorbance reading at A260/280 using Ultrospec ${ }^{\mathrm{TM}} 2100$ pro UV/Visible Spectrophotometer (Amersham Bioscience, Freiburg, Germany).

\section{Aminoallyl indirect labelling and dye coupling}

MIAME (Minimum Information About Microarray Experiments) guidelines were adhered to the experimental design. Two independent labelling reactions were carried out per aRNA sample pertinent to each biological replicate for dye-swap hybridizations. Accordingly, $3 \mu \mathrm{g}$ of aRNA from each oocyte pool representing each follicular phase of development (growth or dominance) was used as template in reverse transcription reactions incorporat- 
ing amino-modified dUTPs into the cDNA using the CyScribe Post-Labelling Kit (Amersham Biosciences, Freiburg, Germany) as described previously $[25,57]$. The aminoallyl labelled cDNA samples were purified using CyScribe $^{\mathrm{TM}}$ GFX $^{\mathrm{TM}}$ Purification kit (Amersham Biosciences) after adding $10 \mu \mathrm{l}$ of $2 \mathrm{M}$ HEPES. The purified Aminoallyl labelled cDNA was then eluted in $60 \mu \mathrm{l} 0.1 \mathrm{M}$ sodium bicarbonate. The cDNA samples from each phase were differentially labelled indirectly using $\mathrm{N}$-hydroxysuccinatederived Cy3 and Cy5 dyes and incubated for $1.5 \mathrm{hrs}$ at room temperature in dark. At the end of incubation, non reacting dyes were quenched by adding $15 \mu \mathrm{l}$ of $4 \mathrm{M}$ hydroxylamine solution (Sigma) and incubated for 15 $\mathrm{min}$ at room temperature in dark. To avoid variation due to dye coupling, aRNA samples from the same follicular phase were labelled reversibly either with $\mathrm{Cy} 3$ or Cy5 for dye swaps hybridizations. The reaction was then purified with CyScribe ${ }^{\mathrm{TM}} \mathrm{GFX}^{\mathrm{TM}}$ Purification kit (Amersham Biosciences, Freiburg, Germany). Samples were finally eluted in $60 \mu \mathrm{l}$ elution buffer.

\section{Probe hybridization}

Pre-hybridization of the slides was performed by placing the array slides into a corning GAPS II slide container as described in El-Sayed et al. [25]. Hybridization and posthybridization washes were carried out as previously described elsewhere [58] with slight modifications. Samples that were going to be hybridized on specific array were mixed and dried in speedvac centrifuge (GMI, Inc. Minnesota, USA) then the pellet was re-suspended in prewarmed $\left(42^{\circ} \mathrm{C}\right)$ formamid based hybridization buffer [15 $\mu \mathrm{l}$ hybridization buffer (Amersham Bioscience, Freiburg, Germany), $30 \mu \mathrm{l} 100 \%$ Formamide, and $15 \mu \mathrm{l}$ DEPC water]. Yeast tRNA $(4 \mathrm{mg} / \mathrm{ml})$ and $2.5 \mu \mathrm{l}$ of Cot-human DNA $(1 \mathrm{mg} / \mathrm{ml})$ (Invitrogen, Karlsruhe, Germany) were added in a volume of $2.5 \mu \mathrm{l}$ each to avoid non specific hybridisation. The pellet was denatured at $95^{\circ} \mathrm{C}$ for 5 min, centrifuged briefly and hybridized to the array. The arrays were covered with glass cover slips (ROTH, Karlsruhe, Germany) and fixed in the hybridisation cassettes (TeleChem International, Inc, CA, USA.) before incubation in a hybridisation chamber (GFL, Dülmen, Germany) at $42^{\circ} \mathrm{C}$ for $16-20$ hrs. After hybridization, slides were washed twice with $2 \times$ SSC- $0.1 \%$ SDS buffer for $5 \mathrm{~min}$ at $42^{\circ} \mathrm{C}$, then once with $1 \times$ SSC, $0.2 \times$ SSC and $0.1 \times$ SSC for $5 \mathrm{~min}$ each at room temperature. Finally, the slides were rinsed in RNA free water then in isopropanol for 1 min each and centrifuged at $\geq 2000 \mathrm{rpm}$ for $2 \mathrm{~min}$.

\section{Custom array characterization}

Ready made bovine cDNA array (BlueChip) [59] provided by Centre de Recherche en Biologie de la Reproduction was used in this study. The glass slide contains 4928 spots divided into two sub-arrays. Each sub-array was composed of 2304 ESTs randomly selected clones obtained from four different subtraction suppressive hybridizations (SSH) made with bovine embryos and tissues (First SSH: GV oocytes subtracted from somatic tissues, second SSH: GV oocytes subtracted from day-8 blastocysts, third SSH: day-8 blastocysts subtracted from GV oocytes and fourth SSH: day-8 blastocysts subtracted from somatic tissues). All the clones were spotted in each sub-array for a total of four replicates per slide. Eleven more samples namely vide (32 spots), alien1 (8 spots), alien2 (8 spots), GFP (4 spots), GFP1 (4 spots), GFP1/2 (4 spots), GFP1/4 (4 spots), GFP1/8 (4 spots), GFP $1 / 16$ (4 spots) and H20/ DMSO (50 spots) were spotted to be used as negative controls for determination of hybridisation background during the statistical analysis. Housekeeping genes including tubulin (8 spots), ubiquitin ( 8 spots), $\beta$-actin ( 6 spots) and actin ( 8 spots) were also added as positive controls.

\section{Array scanning and data analysis}

The slides were scanned using Axon GenePix 4000B scanner (Axon Instruments, Foster City, CA, USA). The GenePix $^{\circledast}$ Pro 4.0 software (Axon Instruments, CA, USA) was used to process the images, to find spots, to integrate robot-spotting files and finally to create reports of spot intensity data. The LOWESS normalization of microarray data was performed using GProcessor 2.0a software [60]. The normalised data were used to calculate intensity ratios of all replicates and to obtain one value per clone. Ratios were finally $\log _{2}$ transformed and submitted to SAM analysis. Microarray data analysis was performed using SAM, free software developed at Stanford University [61]. To get truly differentially expressed genes, the FDR was set at $10 \%$ and P-value of $<0.05$. Hierarchical clustering and heatmap of $\log _{2}$-transformed data for up and down regulated genes were generated using PermutMatrix (version 1.8.2) available at [62]. In addition, average linkage clustering algorithm method was employed [63]. Genes expressed equally in both samples were not included in the hierarchical clustering.

\section{Quantitative real-time PCR analysis}

To validate the results obtained from microarray analysis, 10 candidate transcripts were selected for further analysis using real-time quantitative PCR (Tab. 4). Five of these 10 candidates were further quantified in the corresponding cumulus cells from the oocytes of growth and dominance phases of follicular development. Furthermore, five transcripts were subjected to real-time quantitative PCR using cDNA synthesized form $\mathrm{BCB}^{+}$and $\mathrm{BCB}^{-}$oocytes. In all cases, quantitative analysis of cDNA samples was performed as described previously [25] in comparison with the bovine GAPDH gene (endogenous control), and was run in separate wells using ABI PRISM ${ }^{\otimes} 7000$ sequence detection system (Applied Biosystems, Foster City, CA, USA). Finally quantitative analysis was done using the relative standard curve method and results were reported as 
Table 4: Details of the primers used for real-time quantitative PCR analysis and in situ hybridization

\begin{tabular}{|c|c|c|c|c|}
\hline $\begin{array}{l}\text { Gene } \\
\text { name }\end{array}$ & $\begin{array}{l}\text { Gene bank } \\
\text { accession } \\
\text { Number }\end{array}$ & Primer sequences & $\begin{array}{c}\text { Annealing } \\
\text { temperature }\left({ }^{\circ} \mathrm{C}\right)\end{array}$ & $\begin{array}{l}\text { Product } \\
\text { size (bp) }\end{array}$ \\
\hline \multirow[t]{2}{*}{ BMPI5a } & AY304484 & F: 5'- CTGACGCAAGTGGACACCCTA -3' & 60 & 396 \\
\hline & & R: 5'- GACACACGAAGCGGAGTCGTA -3' & & \\
\hline \multirow[t]{2}{*}{ PTTGIa } & NM 004219 & F: 5'- GAAGAGCACCAGATTGCGC -3' & 55 & 204 \\
\hline & & R: 5'- GTCACAGCAAACAGGTGGCA -3' & & \\
\hline \multirow[t]{2}{*}{ MSXIa } & NM 174798 & F: 5'- AAGGTATCCACAGTCCCCAGC -3' & 55 & 180 \\
\hline & & R: 5'- TCTGCCTCTCCTGCAAAGTTC -3' & & \\
\hline \multirow[t]{2}{*}{$\mathrm{PPa}$} & $\underline{\mathrm{AFI}} 70490$ & F: 5'- GCTGCATCCTACTTGTCGGAA-3' & 55 & 194 \\
\hline & & R: 5'- TTCCAAACTACAACCGCCTTG -3' & & \\
\hline \multirow[t]{2}{*}{ SIOOAIOa } & NMI7468I & F: 5'- GGATTTCTGAGCATATGGGACC -3' & 55 & 131 \\
\hline & & R: 5'- GAGCAAGAGGATGCAAGCAATA -3' & & \\
\hline \multirow[t]{2}{*}{$\mathrm{AN} \times A 2^{\mathrm{a}}$} & NM 174716 & F: 5'- CGTGCTCCAGCTAACAGTTCT-3' & 55 & 139 \\
\hline & & R: 5'- GGAAAGCCAGGTAATGCGTA-3' & & \\
\hline \multirow[t]{2}{*}{$\mathrm{CKS}^{\mathrm{a}}$} & NM 001827 & F: 5'- CGACGACGAGGAGTTCGAGTA-3' & 55 & 122 \\
\hline & & R: 5'- CCTGACTCTGCTGAACACCAAG-3' & & \\
\hline \multirow[t]{2}{*}{ RPL24a } & NM 174455 & F: 5'- CCGTGCAGTCAAATTCCAAA-3' & 55 & 242 \\
\hline & & R: 5'- CAACTCGAGGAGCAGAAACCTT-3 & & \\
\hline \multirow[t]{2}{*}{ FL396a } & AY308068 & F: 5'- CGCCAACACGTCTTATACCAAC-3' & 55 & 201 \\
\hline & & R: 5'- CTGCGAAGAGGCTTCCAATTAG-3' & & \\
\hline \multirow[t]{2}{*}{ CCNBIa } & $\underline{\mathrm{L} 26548}$ & F: 5'- CGATATGGTGCACTTTCCTCC-3' & 55 & 145 \\
\hline & & R: 5'- TGACCACATTCTTTGCCAGG-3' & & \\
\hline \multirow[t]{2}{*}{$\mathrm{GAPDH}^{\mathrm{a}}$} & $\underline{\mathrm{BC}} \mathbf{0 2 5 8 9}$ & F: 5'-ACCCAGAAGACTGTGGATGG-3' & 60 & 247 \\
\hline & & R: 5'-ACGCCTGCTTCACCACCTTC-3' & & \\
\hline \multirow[t]{2}{*}{ MSXIb } & NM 174798 & F:5'-AGAAGCAGTACCTGTCCATCG & 55 & 382 \\
\hline & & R: 5'-GGCCTTCTATGTCAGGTGGTA & & \\
\hline \multirow[t]{2}{*}{ MSXIc } & NM 174798 & T7-F:5'- GTAATACGACTCACTATAGGGAGAAGCAGTACCTGTCCATCG & 55 & 382 \\
\hline & & R: 5'-GGCCTTCTATGTCAGGTGGTA & & \\
\hline \multirow[t]{2}{*}{ MSXId } & NM 174798 & SP6-R:5'- GATTTAGGTGACACTATAGAAGGCCTTCTATGTCAGGTGGTA & 55 & 382 \\
\hline & & F:5'-AGAAGCAGTACCTGTCCATCG & & \\
\hline
\end{tabular}

a The primer used for real-time PCR, b The primer used for DNA template amplification, c The forward primer coupled with T7 promoter (underlined) used for sense probe synthesis, ${ }^{d}$ The reverse primer coupled with SP6 promoter (underlined) used for antisense probe synthesis.

the relative expression or fold change as compared to the calibrator after normalization of the transcript level to the endogenous control [64].

\section{Immunohistochemistry}

Eight Simmental cyclic heifers, two of each at day of estrus (day 0), day of ovulation (day 1), growth phase (day 3) and dominance phase (day 7) were slaughtered to obtain ovaries for MSX1 protein localization using immunohistochemistery. Ovaries were embedded in Tissue-Tek (Sakura Finetek Europe, Zoeterwoude, Netherlands) and snap-frozen in liquid nitrogen and stored at $-80^{\circ} \mathrm{C}$ until sectioning. Serial sections of $5 \mu \mathrm{m}$ were cut at $-20^{\circ} \mathrm{C}$ using rapid sectioning cryostat (Leica microsystem Nussloch GmbH, Heidelberger, Germany). The sections were mounted on poly-L-lysine coated slides (Menzel GmbH \& Co. KG, Braunschweig, Germany) then washed twice in PBS for $5 \mathrm{~min}$ and fixed in $4 \%(\mathrm{w} / \mathrm{v})$ paraformaldehyde in PBS for $45 \mathrm{~min}$ at room temperature. The fixed specimens were permeabilized for 5 min with $0.2 \%(\mathrm{v} / \mathrm{v})$ Triton$\mathrm{X} 100$ (Sigma) in PBS and washed three times with PBS. In order to inhibit non-specific binding of the antibodies, samples were subsequently blocked in 3\% (w/v) bovine serum albumin (BSA) in PBS for $1 \mathrm{hr}$ at $37^{\circ} \mathrm{C}$. After triple washing with $0.3 \%(\mathrm{w} / \mathrm{v})$ BSA in PBS slides were incubated for 15 hrs at $4^{\circ} \mathrm{C}$ with anti-MSX1 primary polyclonal antibody (Sigma) with a dilution of 1:100. After three consecutive washes with $0.3 \%(\mathrm{w} / \mathrm{v}) \mathrm{BSA}$ in PBS, slides were further incubated for 1 hr with 1:100 dilutions of secondary anti-rabbit IgG FITC conjugated antibody (Sigma). Negative controls were processed in the same manner by omitting the primary antibody.

Iin vitro produced bovine oocytes (immature, matured) and early cleavage stages embryos (zygotes, advanced zygotes, 2-cell, 4-cell, 8-cell) were used for immunohistological localization of MSX1 protein. Ten oocytes or embryos from each stage were processed similar to ovarian sections with some modifications. Specimens were fixed in $4 \%(\mathrm{w} / \mathrm{v})$ paraformaldehyde in PBS overnight at $4{ }^{\circ} \mathrm{C}$ and permeabilized by $0.5 \%$ (v/v) Triton-X100 (Sigma) in PBS. In order to inhibit non-specific binding of the antibodies, samples were subsequently blocked in $3 \%$ $(\mathrm{w} / \mathrm{v})$ BSA in PBS for $1 \mathrm{hr}$. The oocytes and embryos were 
then incubated for $1 \mathrm{hr}$ at $39^{\circ} \mathrm{C}$ with 1:100 dilution of anti-MSX1 primary polyclonal antibody (Sigma-Aldrich, St Louis, MO, USA). Oocytes and embryos were finally counterstained with $0.5 \mu \mathrm{g} / \mathrm{ml}$ propidium iodide (SigmaAldrich, St Louis, MO, USA) for $15 \mathrm{~min}$, followed by washing with PBS. Slides were mounted with Vectashield mounting medium, covered with coverslip and viewed under confocal laser scanning microscope (CLSM LSM510, Carl Zeiss, Germany).

\section{In situ hybridization}

Digoxigenin-labeled riboprobes (MSX1 cDNA, sense and antisense) were generated by SP6 and T7 polymerases from linearized pGEM $^{\circledast}$-T Vector plasmid containing a 382 bp MSX1 cDNA insert (details of primers used Tab. 4) using Dig-labeling kit (Roche Diagnostics, Mannheim, Germany), according to the manufacturer's protocol. The same tissue samples that have been used for immunohistochemistery were serially sectioned of $5 \mu \mathrm{m}$ at $-20^{\circ} \mathrm{C}$ as mentioned above. All sections were fixed in $4 \%$ paraformaldehyde at room temperature for $15 \mathrm{~min}$. The RNA probes $(50 \mathrm{ng} / \mu \mathrm{l}$, sense or antisense) were added to hybridisation buffer [ $50 \%$ Dextran sulphate, $2.5 \mathrm{M} \mathrm{NaCL}$, Formamide, $20 \times$ SSC, Yeast tRNA $(10 \mathrm{mg} / \mathrm{ml}), 50 \times$ Denhardt's solution, Fish sperm DNA $(10 \mathrm{mg} / \mathrm{ml})]$, denatured at $80^{\circ} \mathrm{C}$ for $5 \mathrm{~min}$ and incubated overnight at $52^{\circ} \mathrm{C}$ in humidified chamber. Posthybridization washes were in $2 \times \operatorname{SSC}(\mathrm{pH}=8), 50 \%$ formamide twice at $45^{\circ} \mathrm{C}$ and three times at room temperature for $10 \mathrm{~min}$ each. Then sections were treated with $5 \mu \mathrm{g}$ of RNase A and 50 units of RNase T1 (Fermentas, Steinheim, Germany) in $2 \times$ SSC at room temperature for $30 \mathrm{~min}$, followed by three times washing with $2 \times$ SSC at room temperature for $10 \mathrm{~min}$ each. After washing with TN buffer $(0.1 \mathrm{M}$ Tris, $0.15 \mathrm{M} \mathrm{NaCl}, \mathrm{pH} 7.5)$ at room temperature for $5 \mathrm{~min}$, the slides were incubated with 5\% (w/v) blocking buffer (PerKin Elmer, Rodgau Juegesheim, Germany). Then the slides were incubated in a humidified chamber overnight at room temperature with sheep anti-DIG antibody conjugated with horseradish peroxidase (Roth, Karlsruhe, Germany), diluted to 1:100 in buffer 1 containing 1\% blocking reagent. After three times washing with TNT buffer $(0.05 \%$ Tween 20 in $\mathrm{TN}$ buffer) for $5 \mathrm{~min}$ each, the immunoreactions were visualized by incubating the sections with $0.02 \%(\mathrm{w} / \mathrm{v})$ TSA $^{\mathrm{TM}}$-Plus Fluorescent System (Perkin Elmer, Rodgau Juegesheim, Germany). Slides were counterstained with propidiumiodide $(0.5 \mu \mathrm{g} / \mathrm{ml}$ of TNT buffer) and finally mounted with drop of Vecta shield and covered with a cover slip before viewed under fluorescence microscope.

\section{Brilliant cresyl blue staining}

Oocytes aspirated form slaughter house ovaries were used for BCB staining. The procedure of BCB staining is done as described in our previous studies $[52,53]$. Briefly a total of 500 morphologically good quality immature oocytes were subjected to $26 \mu \mathrm{M}$ BCB (B-5388, Sigma-Alderich, Taufenkirchen, Germany) diluted in mDPBS for $90 \mathrm{~min}$ at $38.5^{\circ} \mathrm{C}$ in a humidified air atmosphere. After washing the stained COCs were examined under stereomicroscope and categorized into two groups according to their cytoplasm colouration: oocytes with any degree of blue colouration in the cytoplasm $\left(\mathrm{BCB}^{+}\right)$and oocytes without visual blue colouration ( $\left.\mathrm{BCB}^{-}\right)$. From each group, four pools of oocytes each with 50 oocytes (a total of 200) were used for mRNA isolation and subsequent real-time PCR after removal of cumulus cells as described before.

\section{Statistical analysis}

The mRNA expression analysis for the studied genes was performed based on the relative standard curve method. The relative expression data were analysed using General Linear Model (GLM) of the Statistical Analysis System (SAS) software package version 8.0 (SAS Institute Inc., NC, USA). Differences among the mean values were tested using ANOVA followed by a multiple pair wise comparison using $t$-test. Differences of $P \leq 0.05$ were considered to be significant.

\section{Authors' contributions}

All authors have been contributed equally to this work.

\section{Acknowledgements}

The authors would like to thank Dr. Andreas Waha (Institute of Neuropathology, University of Bonn) for facilitating the use of GenePix scanner and programme during microarray analysis.

\section{References}

I. Hasler JF: The current status of oocyte recovery, in vitro embryo production, and embryo transfer in domestic animals with an emphasis on the bovine. J Anim Sci 1998, 76(suppl 3):52-74.

2. Trounson AO, Pushett D, MacLellon LJ, Lewis J: Current status of IVM/IVF and embryo culture in humans and farm animals. Theriogenology 1994, 41:57-66.

3. Rizos D, Ward F, Duffy P, Boland MP, Lonergan P: Consequences of bovine oocyte maturation, fertilization or early embryo development in vitro versus in vivo: implications for blastocyst yield and blastocyst quality. Mol Reprod Dev 2002, 6 I:234-248

4. Lonergan P, Monaghan P, Rizos D, Boland MP, Gordon I: Effect of follicle size on bovine oocyte quality and developmental competence following maturation, fertilization and culture in vitro. Mol Reprod Dev 1994, 37:48-53.

5. Machatková M, Jokešová E, Petelíková J, Dvoráček V: Developmental competence of bovine embryos derived from oocytes collected at various stages of the estrous cycle. Theriogenology 1996, 45:801-810.

6. Hagemann LJ: Influence of the dominant follicle on oocytes from subordinate follicles. Theriogenology I999, 5 I:449-459.

7. Boni R, Cuomo A, Toti E: Developmental potential in bovine oocytes is related to cumulus-oocyte complex grade, calcium current activity, and calcium stores. Biol Reprod 2002, 66:836-842.

8. Arlotto T, Schwartz JL, First NL, Leibfried-Rutledge ML: Aspects of follicle and oocyte stage that affect in vitro maturation and development of bovine oocytes. Theriogenology 1996, 45:943-956.

9. Albertini DT, Sanfins A, Comelles CM: Origins and manifestations of oocyte maturation competencies. RBM Online 2003, 6:410-415. 
10. Gandolfi F, Brevini TAL, Cillo F, Antonini S: Cellular and molecular mechanisms regulating oocyte quality and the relevance for farm animal reproductive efficiency. Rev Sci Tech Off Int Epiz 2005, 24(I):413-423.

II. Blondin P, Sirard MA: Oocyte and follicular morphology as determining characteristics for developmental competence in bovine oocytes. Mol Reprod Dev 1995, 41:54-62.

12. Seneda MM, Esper CR, Garcia JM, Oliveira JA, Vantini R: Relationship between follicle size and ultrasound-guided transvaginal oocyte recovery. Anim Reprod Sci 200I, 67:37-43.

13. Vassena R, Mapletoft RJ, Allodi S, Singh J, Adams GP: Morphology and developmental competence of bovine oocytes relative to follicular status. Theriogenology 2003, 60:923-932.

14. Pierson RA, Ginther OJ: Ultrasonographic appearance of the bovine uterus during the estrous cycle. J Am vet med Assoc I987, 190:995-1001.

15. Sirois J, Fortune JE: Ovarian follicular dynamics during the estrous cycle in heifers monitored by real-time ultrasonography. Biol Reprod 1988, 39:308-317.

16. Driancourt MA: The regulation of ovarian follicular dynamics in farm animals: Implication for manipulation of reproduction. Theriogenology 200I, 55:121I-1239.

17. Hagemann LJ, Weilert LL, Beaumont S, Tervit HR: Development of bovine embryos in single in vitro production (sIVP) systems. Mol Reprod Dev 1998, 51:143-147.

18. Leibfried-Rutledge ML: Factors determining competence of in vitro produced cattle embryos. Theriogenology 1999, 5 I:473-485.

19. Machatkova M, Jokesova E, Horky F, Krepelova A: Utilization of the growth phase of the first follicular wave for bovine oocyte collection improves blastocyst production. Theriogenology 2000, 54:543-550.

20. Hendriksen PJM, Steenweg WNM, Harkema JC, Merton JS, Bevers MM, Vos PLAM, Dieleman SJ: Effect of different stages of the follicular wave on in vitro developmental competence of bovine oocytes. Theriogenology 2004, 61:909-920.

21. Machatkova M, Krausova K, Jokesova E, Tomanek M: Developmental competence of bovine oocytes: effects of follicle size and the phase of follicular wave on in vitro embryo production. Theriogenology 2004, 61 :329-335.

22. Wood SC, Glencross RG, Bleach EC, Lovell R, Beard AJ, Knight PJ: The ability of steroid-free bovine follicular fluid to suppress FSH secretion and delay ovulation persists in heifers actively immunized against inhibin. J Endocrinol 1993, 136:137-148.

23. Wolfsdorf KE, Diaz T, Smitt EJP, Thatcher MJ, Drost M, Thatcher WW: The dominant follicle exerts an interovarian inhibition on FSH-induced follicular development. Theriogenology 1997 , 48:435-447.

24. Nemcova L, Machatkova M, Hanzalova K, Horakovab J, Kankaa J: Gene expression in bovine embryos derived from oocytes with different developmental competence collected at the defined follicular developmental stage. Theriogenology 2006, 65:1254-1264

25. El-Sayed A, Hoelker M, Rings F, Salilew D, Jennen D, Tholen E, Sirard MA, Schellander K, Tesfaye D: Large-scale transcriptional analysis of bovine embryo biopsies in relation to pregnancy success after transfer to recipients. Physiol Genomics 2006, 28:84-96.

26. Satokata I, Maas R: Msx I deficient mice exhibit cleft palate and abnormalities of craniofacial and tooth development. Nat Genet 1994, 6:348-356.

27. Park J, Park K, Kim S, Lee J-H: Msx I gene overexpression induces GI phase cell arrest in human ovarian cancer cell line OVCAR3 I. Biochem Biophys Res Commun 200I, 28 I:I234-I240.

28. Bonn University [http://www.itw.uni-bonn.de/englisch/groups/ breeding/index.htm]

29. Gene Ontology Consortium Classifications [http://www.gene ontology.org]

30. National Center for Biotechnology Information [http:// http:www.ncbi.nlm.nih.gov/]

31. Patel OV, Bettegowda A, Ireland IJ, Coussens PM, Lonergan P, Smith GW: Functional genomics studies of oocyte competence: evidence that reduced transcript abundance for follistatin is associated with poor developmental competence of bovine oocytes. Reproduction 2007, 133:95-106.

32. Donnison M, Pfeffer PL: Isolation of genes associated with developmentally competent bovine oocytes and quantifica- tion of their levels during development. Biol Reprod 2004, 71:1813-1821.

33. Yao J, Ren X, Ireland JJ, Coussens PM, Smith TP, Smith GW: Generation of a bovine oocyte cDNA library and microarray: resources for identification of genes important for follicular development and early embryogenesis. Physiol Genomics 2004, 1 9:84-92.

34. Fair T, Hulshof SCJ, Boland M, Greve T: Nucleolus ultrastructure and transcriptional activity of bovine oocytes in preantral and early antral follicles. Mol Reprod Dev 1997, 46:208-2I5.

35. Tatemoto $H$, Horiuchi $T$ : Requirement for protein synthesis during the onset of meiosis in bovine oocytes and its involvement in the autocatalytic amplification of maturation-promoting factor. Mol Reprod Dev 1995, 41:47-53.

36. Hyttel $P$ Viuff $D$, Fair T Laurincik J, Thomsen PD, Callesen $H$, Vos PLAM, Hendriksen PJM, Dieleman SJ, Schellander K, Besenfelder U, Greve T: Ribosomal RNA gene expression and chromosome aberrations in bovine oocytes and preimplantation embryos. Reproduction 200I, I 22:21-30.

37. Eichenlaub-Ritter U, Peschke $M$ : Expression in in-vivo and invitro growing and maturing oocytes: focus on regulation of expression at the translational level. Hum Reprod Update 2002, 8:21-4I.

38. Fair T, Hyttel P, Greve T, Lonergan P, Boland MP: Immunolocalization of nucleolar proteins during bovine oocyte growth, meiotic maturation, and fertilization. Biol Reprod 200I, 64:1516-1525.

39. Vigneault C, McGraw S, Massicotte L, Sirard MA: Transcription factor expression patterns in bovine in vitro-derived embryos prior to maternal-zygotic transition. Biol Reprod 2004, 70:1701-1709.

40. Davidson D: The function and evolution of Msx genes: pointers and paradoxes. Trends Genet 1995, II:405-4I I.

41. Favier B, Dolle P: Developmental functions of mammalian Hox genes. Mol Hum Reprod 1997, 3: I I5-I3I.

42. Park J, Park K, Kim S, Lee J-H: Msx I gene overexpression induces GI phase cell arrest in human ovarian cancer cell line OVCAR3 I. Biochem Biophys Res Commun 200I, 28 I:I234-I 240.

43. Park K, Kim K, Rho SB, Choi K, Kim D, Oh SH, Park J, Lee SH, Lee J: Homeobox Msxl interacts with p53 tumor suppressor and inhibits tumor growth by inducing apoptosis. Cancer Res 2005, 65:749-757.

44. Satokata I, Maas R: Msx I deficient mice exhibit cleft palate and abnormalities of craniofacial and tooth development. Nat Genet 1994, 6:348-356.

45. Pei L, Melmed S: Isolation and characterization of a pituitary tumor transforming gene (PTTG). Mol Endocrinol 1997. I I:433-44 I.

46. Hamid T, Kakar SS: PTTG/securin activates expression of p53 and modulates its function. Mol Cancer 2004, 3: 18.

47. Deb K, Sivaguru M, Yong HY, Roberts RM: Cdx2 gene expression and trophectoderm lineage specification in mouse embryos. Science 2006, 3 I I:992-996.

48. Sterneck E, Tessarollo L, Johnson PF: An essential role for C/ EBPB in female reproduction. Genes Dev 1997, II:2153-2162.

49. Elvin JA, Yan C, Wang P, Nishimori K, Matzuk MM: Molecular characterization of the follicle defects in the growth factor-9-deficient ovary. Mol Endocrinol 1999, 13:1018-1034.

50. Brower PT, Schultz RM: Intercellular communication between granulosa cells and mouse oocytes: existence and possible role during oocyte growth. Dev Biol I982, 90:144-I53.

51. Downs SM: A gap-junction-mediated signal, rather than an external paracrine factor, predominates during meiotic induction in isolated mouse oocytes. Zygote 200I, 9:7I-82.

52. Assou S, Anahory T, Pantesco V, Le Carrour T, Pellestor F, Klein B, Reyftmann L, Dechaud H, De Vos J, Hamamah S: The human cumulus-oocyte complex gene-expression profile. Hum Reprod 2006, $21: 1705-1719$.

53. McKenzie LJ, Pangas SA, Carson SA, Kovanci E, Cisneros P, Buster JE, Amato $P$, Matzuk MM: Human cumulus granulosa cell gene expression: a predictor of fertilization and embryo selection in women undergoing IVF. Hum Reprod 2004, 19:2869-2874.

54. Zhang X, Jafari N, Barnes RB, Confino E, Milad M, Kazer RR: Studies of gene expression in human cumulus cells indicate pentraxin 3 as a possible marker for oocyte quality. Fertil Steril 2005, 83:1169-1179. 
55. Alm H, Torner H, Loehrke B, Viergutz T, Ghoneim IM, Kanitz W: Bovine blastocyst development rate in vitro is influenced by selection of oocytes by brilliant cresyl blue staining before IVM as indicator for glucose-6-phosphate dehydrogenase activity. Theriogenology 2005, 63:2194-2205.

56. Bhojwani S, Alm H, Torner H, Kanitz W, Poehland R: Selection of developmentally competent oocytes through brilliant cresyl blue stain enhances blastocyst development rate after bovine nuclear transfer. Theriogenology 2007, 67:34I-354.

57. Mamo E, Sargent CA, Affara NA, Tesfaye D, El-Halawany N, Wimmers K, Gilles M, Schellander K, Ponsuksili S: Transcripts profiles of some developmentally important genes detected in bovine oocytes and in vitro-produced blastocysts using RNA amplification and cDNA microarrays. Reprod Dom Anim 2006, 41:527-534.

58. Hedge P, Qi R, Abernathy R, Gay C, Dharap S, Gaspard R, EarleHughes J, Snesrud E, Lee NH, Quackenbush JA: A concise guide to cDNA microarray analysis. BioTechniques 2000, 29:548-546.

59. Sirard MA, Dufort I, Vallee M, Massicotte L, Gravel C, Reghenas H, Watson AJ, King WA, Robert C: Potential and limitations of bovine-specific arrays for the analysis of mRNA levels in early development: preliminary analysis using a bovine embryonic array. Reprod Fertil Dev 2005, 17:47-57.

60. Zhao's Lab of Statistical Genomics and Proteomics [http:// bioinformatics.med.yale.edu/group/]

61. Stanford University [http://www-stat.stanford.edu/ tibs/SAM/]

62. Le Laboratoire d'Informatique, de Robotique et de Microélectronique de Montpellier [http://www.lirmm.fr/ caraux/Per mutMatrix/]

63. Eisen MB, Spellman PT, Brown PO, Botstein D: Cluster analysis and display of genome-wide expression patterns. Proc Natl Acad Sci 1998, 95: 14863-14868.

64. Tesfaye D, Ponsuksili S, Wimmers K, Gilles M, Schellander K: A comparative expression analysis of gene transcripts in post-fertilization developmental stages of bovine embryos produced in vitro or in vivo. Reprod Dom Anim 2004, 39:396-404.

Publish with Bio Med Central and every scientist can read your work free of charge

"BioMed Central will be the most significant development for disseminating the results of biomedical research in our lifetime. "

Sir Paul Nurse, Cancer Research UK

Your research papers will be:

- available free of charge to the entire biomedical community

- peer reviewed and published immediately upon acceptance

- cited in PubMed and archived on PubMed Central

- yours - you keep the copyright 